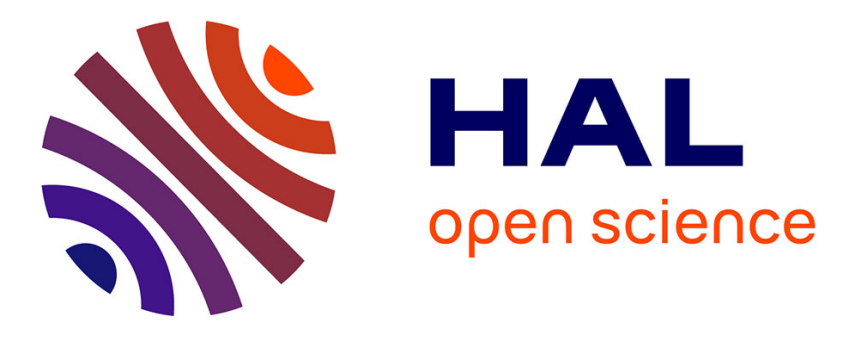

\title{
Electrotriggered Confined Self-assembly of Metal-Polyphenol Nanocoatings Using a Morphogenic Approach
}

Clément Maerten, Lionel Lopez, Paolo Lupattelli, Gaulthier Rydzek, Sergey Pronkin, Pierre Schaaf, Loïc Jierry, Fouzia Boulmedais

\section{To cite this version:}

Clément Maerten, Lionel Lopez, Paolo Lupattelli, Gaulthier Rydzek, Sergey Pronkin, et al.. Electrotriggered Confined Self-assembly of Metal-Polyphenol Nanocoatings Using a Morphogenic Approach. Chemistry of Materials, 2017, 29 (22), pp.9668-9679. 10.1021/acs.chemmater.7b03349 . hal02456536

\section{HAL Id: hal-02456536 https://hal.science/hal-02456536}

Submitted on 27 Jan 2020

HAL is a multi-disciplinary open access archive for the deposit and dissemination of scientific research documents, whether they are published or not. The documents may come from teaching and research institutions in France or abroad, or from public or private research centers.
L'archive ouverte pluridisciplinaire HAL, est destinée au dépôt et à la diffusion de documents scientifiques de niveau recherche, publiés ou non, émanant des établissements d'enseignement et de recherche français ou étrangers, des laboratoires publics ou privés. 


\section{Electrotriggered confined self-assembly of metal-}

\section{polyphenol nanocoatings using a morphogenic}

\section{approach}

Clément Maerten, ${ }^{1,+}$ Lionel Lopez, ${ }^{1,+}$ Paolo Lupattelli, ${ }^{1,2,3}$ Gaulthier Rydzek ${ }^{4,5}$ Sergey Pronkin ${ }^{6,7}$

Pierre Schaaf, ${ }^{1,2,6,8,9,10,11}$ Lö̈c Jierry ${ }^{1,6}$ and Fouzia Boulmedais ${ }^{1,2, *}$

${ }^{1}$ Université de Strasbourg, CNRS, Institut Charles Sadron UPR 22, 67000 Strasbourg, France

${ }^{2}$ University of Strasbourg Institute of Advanced Study, 67083 Strasbourg, France.

${ }^{3}$ Dipartimento di Scienze, Università degli studi della Basilicata, 85100 Potenza, Italy.

4 World Premier International (WPI) Research Center for Materials Nanoarchitectonics (MANA), National Institute for Materials Science (NIMS), Tsukuba 305-0044, Japan

5 International Center for Young Scientists (ICYS), National Institute for Materials Science (NIMS), Tsukuba 305-0044, Japan

${ }^{6}$ Université de Strasbourg, Ecole de Chimie, Polymères et Matériaux, 67087 Strasbourg, France.

7 Université de Strasbourg, CNRS, ICPEES UMR 7515, 67087 Strasbourg, France.

${ }^{8}$ Institut National de la Santé et de la Recherche Médicale, INSERM Unité 1121, 67085

Strasbourg, France

${ }^{9}$ Université de Strasbourg, Faculté de Chirurgie Dentaire, Fédération de Médecine

Translationnelle de Strasbourg (FMTS), and Fédération des Matériaux et Nanoscience d'Alsace (FMNA), 67000 Strasbourg, France.

${ }^{10}$ International Center for Frontier Research in Chemistry, 67083 Strasbourg, France.

${ }^{+}$Both authors contributed equally 


\begin{abstract}
Supramolecular metal-phenolic thin films attract an increasing interest since they allow the design of new types of self-assembling materials, such as tunable electronics or biomaterials. In this study, a new electrotriggered self-assembly of tannic acid-Fe(III) (TA-Fe(III)) nanocoatings was developed using the morphogenic approach with Fe(III) ions as a morphogen. Morphogens are molecules or ions produced locally that diffuse into the solution and induce a chemical reaction or interaction in a confined space near a surface. Using a mixture of TA and $\mathrm{Fe}(\mathrm{II})$ ions in contact with an electrode, a confined electrogenerated gradient of $\mathrm{Fe}(\mathrm{III})$ was obtained by application of an anodic current to locally form TA-Fe(III) coordination complexes. TA-Fe(III) nanocoatings, based on di- and tri-coordinated complexes, were thus obtained. Both the film thickness and its self-assembly kinetic were tuned by controlling $\mathrm{Fe}(\mathrm{II}) / \mathrm{TA}$ molar ratio of the building solution, the intensity and the duration of the applied current. We showed that this strategy can be applied to two other polyphenols (gallic acid and rosmarinic acid). This new electrotriggered confined self-assembly of metal - polyphenol gives new perspectives in application such as anti-oxidant coating.
\end{abstract}




\section{Introduction}

Studied since the first quarter of $\mathrm{XX}^{\text {th }}$ century, surface coatings are largely present in our daily life, conferring new functionalities to materials such as magnetic, electrical, optical, biocompatible or catalytic properties. Many processes were developed in the last decades to functionalize all types of materials (metals, ceramics or polymers) depending on the required property. Supramolecular and molecular nanostructures attract an increasing interest since they allow the design of new types of self-assembling materials, such as tunable electronics or biomaterials. ${ }^{1}$ A large variety of supramolecular interactions, including hydrogen bonding, hydrophobic interactions, ${ }^{2} \pi-\pi$ stacking, ${ }^{3}$ electrostatic interactions, ${ }^{4}$ and metal-ligand coordination $^{5}$ were used to self-assemble molecular architectures on surfaces. Individual metalligand coordination sites can provide stable, yet reversible, crosslinking points between polymers to achieve their self-assembly. Incorporating metal-ions into a supramolecular architecture can improve their properties with potential applications for magnetic, electric and optical devices. ${ }^{6}$ Most often the reported supramolecular self-assembly processes take place in the bulk whereas in Nature such processes are often generated locally. Biomineralization processes overcome the propensity of the different molecules to interact rapidly and spontaneously by heterogeneous nucleation initiated by specific proteins. ${ }^{7}$ At a higher structural level, self-organizations resulting in complex tissue morphologies are driven by morphogenetic fields, through production and diffusion of morphogens. ${ }^{8}$ In analogy with developmental biological processes, a morphogen is defined as a molecule or an ion that is produced at an interface and diffuses into the solution, thus creating a concentration gradient, and that locally induces a chemical process. Localized self-assembly of compounds, present in solution, represents a real challenge, since such compounds are prone to interact in solution. To mimic Nature process, a local stimulus is thus required to initiate the self-assembly process. Electrotriggered reactions constitute one way to 
address this challenge. Electrotriggered formation of films can be divided into three categories: ${ }^{9}$ (i) precipitation of polyelectrolytes by local change of solubility, ${ }^{10-12}$ (ii) self-assemblies of polyelectrolytes through electrostatic/ionic interactions, ${ }^{13-20}$ and (iii) formation of covalent bonds between monomers (electropolymerization) ${ }^{21}$ and between two polymers. ${ }^{22}$ In 2011 , we introduced the morphogenic self-construction of films based on electrogenerated ions that induce the buildup of a film: a new concept in the field of electrodeposition of polymers. ${ }^{23}$ In order to induce the cross-linking between two polymers chains, we first used the $\mathrm{Cu}^{\mathrm{I}}$-catalyzed click reaction between azide and alkyne. ${ }^{24}$ More recently, we described the electrotriggered assembly of polyelectrolytes by using charge shifting polymers allowing the localized deposition of active enzymes. $^{25}$

Inspired by the exceptional ability of mussels to adhere on almost any type of surfaces and by catechol based biochemistry behind this adhesion, a huge community of researchers designed different functional materials. ${ }^{26-27}$ Indeed, catechol can interact with atoms or chemical functions in different ways: ${ }^{28}$ it can form hydrogen bonds, metal-ligand complexes, especially with $\mathrm{Fe}(\mathrm{III})$ ions, charge-transfer complexes and when oxidized covalent bonds with nucleophiles (amines, thiol). Based on the latter property, we recently described a new one-pot electro-cross-linking deposition of polyamine through the confined oxidation of bis-catechol homobifunctional molecules. ${ }^{29}$ Catecholic ligands with Fe(III) ions is one particular metalligand interaction widely observed in Nature with a stability constant of ferric ion complexes equal to $10^{52}$, in the same order as a covalent bond. In addition to its strength and dynamic nature, catechol-Fe(III) complexation is highly $\mathrm{pH}$-dependent. Its binding stoichiometry changes from a 1:1 catechol:Fe(III) mono-complex at low $\mathrm{pH}$ to a highly stable 3:1 tris-complex upon $\mathrm{pH}$ increase. Tannic acid (TA) is a polyphenol, composed of gallic and catecholic moieties present in 
abundance in nature and easily accessible. As catecholic ones, gallic moieties coordinate metals such as $\mathrm{Fe}(\mathrm{III})$ in a $\mathrm{pH}$ dependent manner. At high $\mathrm{pH}$ values (above its $\mathrm{pKa} 8.5$ ), TA behaves as a rigid polyanion and can also form polyelectrolytes complexes with polycations like quaternized poly(4-vinylpyridine),$^{30}$ or poly(allylamine), ${ }^{31}$ proteins, ${ }^{32-33}$ peptides $^{34}$ and antibiotic. ${ }^{35}$ TA$\mathrm{Fe}(\mathrm{III})$ multilayer films were developed using metal-polyphenol coordination. ${ }^{36-38}$ In 2013, Caruso and coworkers introduced a new concept, the one-pot assembly of TA-Fe(III) films and capsules. ${ }^{5}$ By mixing Fe(III) ions and TA in alkaline solution, TA-Fe(III) coatings were selfassembled by a simple dipping of the substrate (planar surfaces or microparticles). The concept was extended to other metallic ions such as aluminium, vanadium, chromium, cobalt ${ }^{39}$ and to small phenolic molecules, such as gallic acid, pyrogallol and pyrocatechol. ${ }^{40}$ Metal-phenolic networks (MPN) are emerging versatile coatings, assembled on polymers, graphene oxide or bacteria, with already several applications reported in the literature, ${ }^{41}$ such as nanofiltration, ${ }^{42}$ catalysis ${ }^{39}$ drug-delivery ${ }^{43}$ or cyto-protective coatings ${ }^{44}$ and self-healing materials. ${ }^{45-46}$ Recently, Rahim et al. investigated rusted iron objects as solid-state iron sources for the fabrication MPN. Chelate complexes of gallic acid and Fe(III) (via etching of the rust layer) were generated to selfassemble stable networks on colloidal substrates present in the solution. ${ }^{47-48}$

Here going one step further, we introduce a new electrotriggered morphogenic selfassembly based on MPN with tunable physico-chemical properties. A mixture solution of TA and $\mathrm{Fe}(\mathrm{II})$, forming a water-soluble ferrous complex,${ }^{49}$ was used as building solution in contact with a working electrode. The application of an anodic current allowed the oxidation of Fe(II) into Fe(III) forming a confined gradient in the vicinity of the electrode and inducing the localized self-assembly of a TA-Fe(III) film (Figure 1). Both film thickness and self-assembly kinetic were tuned by controlling $\mathrm{Fe}(\mathrm{II}) / \mathrm{TA}$ molar ratio of the building solution, the intensity and the duration 
of the applied current. In contrast to Ejima et al. work, ${ }^{5}$ the electrotriggered self-assembly of $\mathrm{Fe}(\mathrm{III}) / \mathrm{TA}$ allows to localize the buildup by localized electrogeneration of $\mathrm{Fe}(\mathrm{III})$ ions on the surface of an electrode and to finely tune the thickness of the coating by switching on and off the electrical stimulus. This new electrotriggered confined self-assembly of metal - polyphenol gives new perspectives for the development of anti-oxidant coatings and versatile functionalizable platforms. Indeed until now, these hybrid coatings were obtained through dissolution of the metallic working electrode acting as the source of metal ions with the anodic method..$^{50-51}$

a

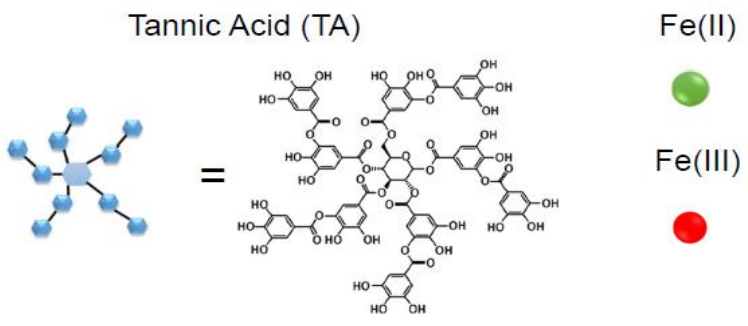

b
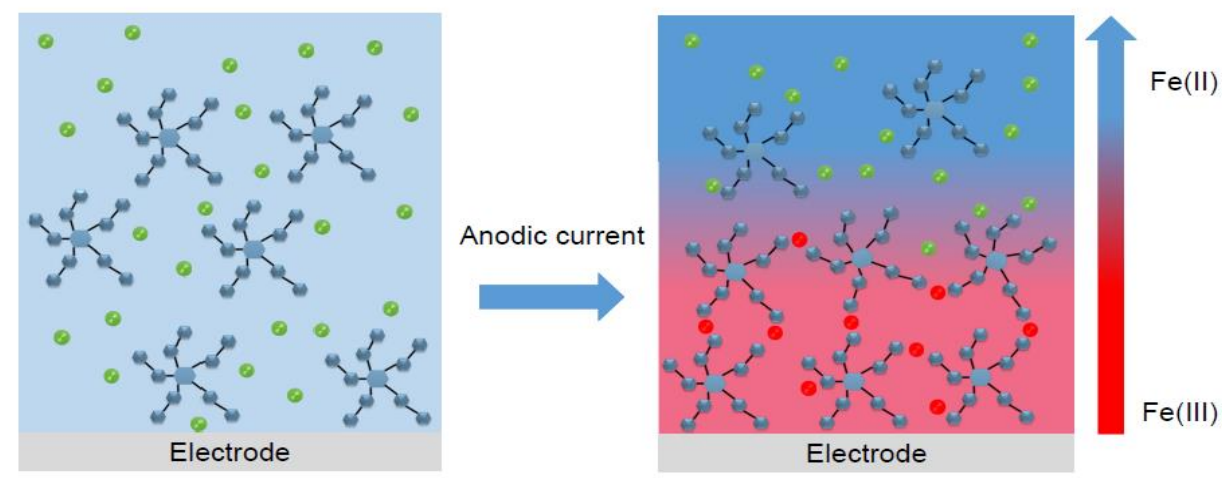

Figure 1: (a) Chemical structure of tannic acid (TA) (b) Schematic representation of the one pot self-assembly of a MPN film based on the electro-oxidation of $\mathrm{Fe}(\mathrm{II})$ in $\mathrm{Fe}(\mathrm{III})$.

\section{Material and methods}

Chemicals. Tannic acid (TA) $(\mathrm{M}=1701.23 \mathrm{~g} / \mathrm{mol}$, CAS 1401-55-4) was purchased from Alfa Aesar. Iron (II) sulfate heptahydrate (Fe(II), $\mathrm{M}=278.01 \mathrm{~g} / \mathrm{mol}$, CAS 7782-63-0), potassium 
hexafluorophosphate $\left(\mathrm{KPF}_{6}\right)(\mathrm{M}=184.06 \mathrm{~g} / \mathrm{mol}$, CAS 17084-13-8), potassium hexacyanoferrate (II) $(\mathrm{M}=422.41 \mathrm{~g} / \mathrm{mol}$, CAS 14459-95-1), Ethylenediaminetetraacetic acid disodium salt dehydrate (EDTA, $\mathrm{Mw}=372.24,6381-92-6$ ) were purchased from Sigma-Aldrich. All chemicals were used as received. All the solutions were prepared using $150 \mathrm{mM} \mathrm{KPF}_{6}$ aqueous solutions adjusted at $\mathrm{pH} 3$ with $\mathrm{KOH}$ and $\mathrm{HNO}_{3}$ aqueous solutions unless otherwise stated. $\mathrm{TA} / \mathrm{Fe}$ (II) mixture solutions were prepared at $10 \mathrm{mg} / \mathrm{mL}$ in $\mathrm{TA}$ and $4.06 \mathrm{mg} / \mathrm{mL}$ in $\mathrm{Fe}$ (II) corresponding to a $\mathrm{Fe}(\mathrm{II}) / \mathrm{TA}$ molar ratio of 2.5, unless otherwise stated. Argon was flushed in all the $\mathrm{TA} / \mathrm{Fe}(\mathrm{II})$ solutions to prevent oxidation in solution due to dissolved oxygen.

Electrochemical Quartz Crystal Microbalance (QCM) with Dissipation Monitoring. The electrochemical quartz microbalance (QCM) experiments were performed on a Q-Sense E1 apparatus from Q-Sense AB (Gothenburg, Sweden) by monitoring the changes in the resonance frequency $f_{v}$ and the dissipation factor $D_{v}$ of an oscillating quartz crystal upon adsorption of a viscoelastic layer ( $v$ represents the overtone number, equal to $1,3,5,7)$. The quartz crystal was excited at its fundamental frequency $(5 \mathrm{MHz})$, and the measurements were performed at the first, third, fifth, and seventh overtones, corresponding to 5, 15, 25, and $35 \mathrm{MHz}$ respectively. The QCM measurement is sensitive to the amount of water associated with the adsorbed molecules and senses the viscoelastic changes in the electrode/electrolyte interface. Only the third overtone at $15 \mathrm{MHz}$ is presented. The indium tin oxide (ITO)-coated QCM (ITO-QCM, MicroVacuum Ltd, Budapest, Hungary) sensor acted as working electrode. A platinum electrode (counter electrode) on the top of the EC-QCM cell and a no-leak $\mathrm{Ag} / \mathrm{AgCl}$ reference electrode fixed in the outlet flow channel were used respectively as counter and reference electrodes. All potentials in the manuscript are referred to $\mathrm{Ag} / \mathrm{AgCl}$ reference electrode. Electrochemical measurements were performed on a CHI660E apparatus from $\mathrm{CH}$ instrument (Austin, Texas) coupled on the QCM-D 
apparatus. Before the buildup of the film, ITO-QCM crystal was cleaned by UV-ozone treatment for $15 \mathrm{~min}$. In order to test the quality of the QCM cell, a capacitive current and a faradic current of ITO electrode in a $1 \mathrm{mM}$ of potassium hexacyanoferrate (II) aqueous solution were recorded. A $150 \mathrm{mM} \mathrm{KPF}_{6}$ solution was prepared to measure the capacitive current of the QCM electrode. $1 \mathrm{mM}$ of potassium hexacyanoferrate (II) was prepared in $150 \mathrm{mM} \mathrm{KPF}_{6}$ solution and put in contact with the crystal to monitor its cyclic voltammogram taken as reference. We verified the presence of the two peaks and the potential values of redox reactions of the $\mathrm{Fe}(\mathrm{II}) / \mathrm{Fe}(\mathrm{III})$ complexes. A surface area of $0.8 \mathrm{~cm}^{2}$, corresponding to the exposed area of the ITO QCM sensor, was used for current density calculations. ${ }^{52}$

Film buildup procedure. To ensure enough ionic conductivity of the building solutions, all the experiments of electrotriggered self-assembly of TA-Fe(III) film were performed in the presence of $150 \mathrm{mM} \mathrm{KPF}_{6}$. After stabilization of the QCM signal in contact with $150 \mathrm{mM} \mathrm{KPF}_{6}$ solution, a mixture of $\mathrm{TA}$ and iron (II) (in $150 \mathrm{mM} \mathrm{KPF}_{6}$ solution, at $\mathrm{pH}=3$ ) was injected in the electrochemical cell $(600 \mu \mathrm{L})$ at a flow rate of $600 \mu \mathrm{L} / \mathrm{min}$ with a peristaltic pump. After stabilization of the signal, a constant anodic current was applied to trigger the iron (II) oxidation into iron (III) and start the self-assembly of the film. After the self-assembly, the current was interrupted and a rinsing step was performed by injection of an aqueous solution of $150 \mathrm{mM}$ $\mathrm{KPF}_{6}(600 \mu \mathrm{L})$. The ITO working electrode was then removed from the EC-QCM cell, rinsed and stored into ultra-pure water for further characterizations in AFM.

Atomic Force Microscopy. Self-constructed films, built on QCM crystals, were characterized by AFM. AFM images were obtained in contact mode in liquid conditions with the Nanoscope IV from Veeco (Santa Barbara, CA). Cantilevers with a spring constant of $0.03 \mathrm{~N} / \mathrm{m}$ and silicon nitride tips (model MSCTAUHW, Veeco) were used. We always performed several scans over a 
given surface area. These scans had to produce comparable images to ascertain that there is no sample damage induced by the tip. Deflection and height images were scanned at a fixed scan rate $(1 \mathrm{~Hz})$ with a resolution of $512 \times 512$ pixels. The film thickness was measured by using the "scratch" method. The scratches were achieved with a plastic cone tip and were always imaged perpendicular to the fast scan axis. Profilometric section analysis of a scratched film allowed us to determine precisely the thickness of the film over the scanned area. We define the film thickness as the minimal $z$ distance between the bare substrate and the surface of the film which covers the whole substrate. The mean thickness of the scratched film was determined by measuring the thickness on at least three areas. The film roughness is the RMS given by the AFM software on $10 \times 10 \mu \mathrm{m}^{2}$ images. Data evaluations were performed with the NanoScope software version 5.31r1 (Digital Instruments, Veeco).

Wettability characterization. Contact angle measurements were performed with a DIGIDROPGBX ${ }^{\circledR}$ coupled with a camera by using $3 \mu \mathrm{L}$ pure water droplets. Values result from the average of three independent measurements done at different area of non-functionalized (before and after UV-ozone treatment) and TA-Fe(III) functionalized ITO-QCM crystals. TA-Fe(III) film was self-assembled with a mixture of TA/Fe(II) (with $2.5 \mathrm{Fe}$ (II)/TA molar ratio prepared in $150 \mathrm{mM}$ $\mathrm{KPF}_{6}$ solution at $\mathrm{pH}=3$ ) by applying a constant anodic current of $6.25 \mu \mathrm{A} / \mathrm{cm}^{2}$ for $30 \mathrm{~min}$. Three rinsing steps were thus performed: a first on by injecting $600 \mu \mathrm{L}$ of $150 \mathrm{mM} \mathrm{KPF}_{6}$ solution at $\mathrm{pH}=3$, the second one by injecting $600 \mu \mathrm{L}$ of MilliQ water at $\mathrm{pH}=3$ and a last one by injecting $600 \mu \mathrm{L}$ of MilliQ water at $\mathrm{pH} 5.8$. The sample was kept in dry state before contact angle measurements.

X-ray Photoelectron Spectroscopy. Chemical composition of the films was determined by X-ray photoelectron spectroscopy (XPS) analysis. This analysis was performed with a PHI Quantera 
SXM (ULVAC-PHI) spectrometer equipped with an Al $\mathrm{K} \alpha$ X-ray source $(1486.6 \mathrm{eV})$. It operated at $100 \mathrm{~W}$ under ultrahigh vacuum (pressure lower than $5.0 \times 10^{-8} \mathrm{mbar}$ ). The incidence angle and the source-to-analyzer angle were set to $45^{\circ}$. The probing depth of the technique was estimated to range from 5 to $8 \mathrm{~nm}$. The survey scans were collected from 0 to $1100 \mathrm{eV}$ with pass energy of $280 \mathrm{eV}$ and the high resolution scans were performed with the pass energy adjusted to $55 \mathrm{eV}$. Raw areas determined after background subtraction were corrected according to Scofield sensitivity factors (C 1s: 1.00, N 1s: 1.80 and $\mathrm{O}$ 1s: 2.93). The curve fitting was performed with CasaXPS software, by using a convolution of Gaussian and Lorentzian line shapes with a typical ratio of 60:40. This peak-fitting procedure was repeated until an acceptable fit was obtained with consideration of peak position and full width at half-maximum.

Stability tests. Using QCM, the stability of TA-Fe(III) films, self-assembled at $\mathrm{pH} 3$ and $\mathrm{pH} 7.4$, was tested towards $100 \mathrm{mM}$ EDTA prepared in $150 \mathrm{mM} \mathrm{KPF}_{6}$ and adjusted at $\mathrm{pH} 3$ and $\mathrm{pH} 7.4$, respectively. After stabilization of the QCM signal in contact with a $150 \mathrm{mM} \mathrm{KPF}_{6}$ solution at $\mathrm{pH}=3$ (resp. $\mathrm{pH} 7.4$ ), a mixture of TA/Fe(II) (with $2.5 \mathrm{Fe}(\mathrm{II}) / \mathrm{TA}$ molar ratio prepared in 150 $\mathrm{mM} \mathrm{KPF}_{6}$ solution) at $\mathrm{pH}=3$ (resp. $\mathrm{pH}$ 7.4) was injected in the electrochemical cell $(600 \mu \mathrm{L})$ at a flow rate of $600 \mu \mathrm{L} / \mathrm{min}$ with a peristaltic pump. After stabilization of the signal, a constant anodic current of $6.25 \mu \mathrm{A} / \mathrm{cm}^{2}$ was applied for $30 \mathrm{~min}$. After the self-assembly, the current was interrupted and a rinsing step was performed by injection of an aqueous solution of $150 \mathrm{mM}$ $\mathrm{KPF}_{6}(600 \mu \mathrm{L}$ injected at a flow rate of $600 \mu \mathrm{L} / \mathrm{min})$ at $\mathrm{pH} 3$ (resp. $\mathrm{pH}$ 7.4). $100 \mathrm{mM}$ EDTA solution, prepared in $150 \mathrm{mM} \mathrm{KPF}_{6}$ and adjusted at $\mathrm{pH} 3$ (resp. $\mathrm{pH}$ 7.4), was put in contact under a flow rate of $600 \mu \mathrm{L} / \mathrm{min}$ with the self-assembled TA-Fe(III) film at $\mathrm{pH} 3$ (resp. $\mathrm{pH}$ 7.4). The percentage of the remaining film was calculated by dividing the value of the normalized frequency shift by the value measured before the injection of EDTA, both measured at $15 \mathrm{MHz}$ 
under the flow condition $(600 \mu \mathrm{L} / \mathrm{min})$. The stability of the film towards $\mathrm{pH}$ changes was performed on TA-Fe(III) film self-assembled at $\mathrm{pH} 3$ for 30 min by injection of $150 \mathrm{mM} \mathrm{KPF}_{6}$ solution at $\mathrm{pH} 12(600 \mu \mathrm{L}$ at a flow rate of $50 \mu \mathrm{L} / \mathrm{min})$ followed by the injection of $150 \mathrm{mM}$ $\mathrm{KPF}_{6}$ solution at $\mathrm{pH} 3(600 \mu \mathrm{L}$ at a flow rate of $50 \mu \mathrm{L} / \mathrm{min})$. Before each injection, the QCM signal reached the stabilization.

Other phenolic molecules film buildup. After stabilization of the QCM signal in contact with 150 $\mathrm{mM} \mathrm{KPF}_{6}$ solution, a mixture of gallic acid/Fe(II) mixture $(1: 2 \mathrm{Fe}(\mathrm{II}) /$ gallic acid molar ratio in $150 \mathrm{mM} \mathrm{KPF}_{6}$ at $\mathrm{pH}$ 3) or rosmarinic acid/Fe(II) mixture (1:1 $\mathrm{Fe}(\mathrm{II}) /$ rosmarinic acid molar ratio in $150 \mathrm{mM} \mathrm{KPF}_{6}$ at $\left.\mathrm{pH} 3\right)$ was injected in the electrochemical cell $(600 \mu \mathrm{L})$ at a flow rate of 600 $\mu \mathrm{L} /$ min with a peristaltic pump. After stabilization of the signal, a constant anodic current $\left(62.5 \mu \mathrm{A} / \mathrm{cm}^{2}\right.$ in the case of gallic acid and $6.25 \mu \mathrm{A} / \mathrm{cm}^{2}$ in the case of rosmarinic acid) was applied to trigger the iron (II) oxidation into iron (III). After the self-assembly, the current was interrupted and a rinsing step was performed by injection of an aqueous solution of $150 \mathrm{mM}$ $\mathrm{KPF}_{6}(600 \mu \mathrm{L})$.

\section{Results and discussion}

Fe(II) and TA electrochemical characterization. We first investigated the electrochemical response of Fe(II), Tannic Acid (TA) and Fe(II)/TA mixtures (Figure 2) by cyclic voltammetry on an ITO coated QCM acting as working electrode. Argon was flushed in all Fe(II) based solutions to prevent from oxidation in solution due to dissolved oxygen. The supporting electrolyte was $150 \mathrm{mM} \mathrm{KPF}_{6}$ buffer solution at $\mathrm{pH} 3$ (unless otherwise stated). The voltammogram of iron ions, obtained at a scan rate of $50 \mathrm{mV} / \mathrm{s}$, exhibit a couple of redox peaks which corresponds to the redox transitions $\mathrm{Fe}(\mathrm{II}) / \mathrm{Fe}(\mathrm{III})$. Oxidation and reduction peaks are centered at $1.2 \mathrm{~V}$ and $-0.05 \mathrm{~V}$, respectively (Figure 2a), with $\mathrm{Fe}(\mathrm{II})$ oxidation observed for 
potentials above $0.2 \mathrm{~V}$. These values are quite different compared to the literature which were measured on a bare gold electrode $\left(0.70 \mathrm{~V}\right.$ and $0.29 \mathrm{~V}$, respectively) ${ }^{53}$ The wider separation of redox peaks is probably related to slower kinetics of $\mathrm{Fe}(\mathrm{II}) / \mathrm{Fe}(\mathrm{III})$ transition on ITO compared to gold electrode. ${ }^{54}$

a
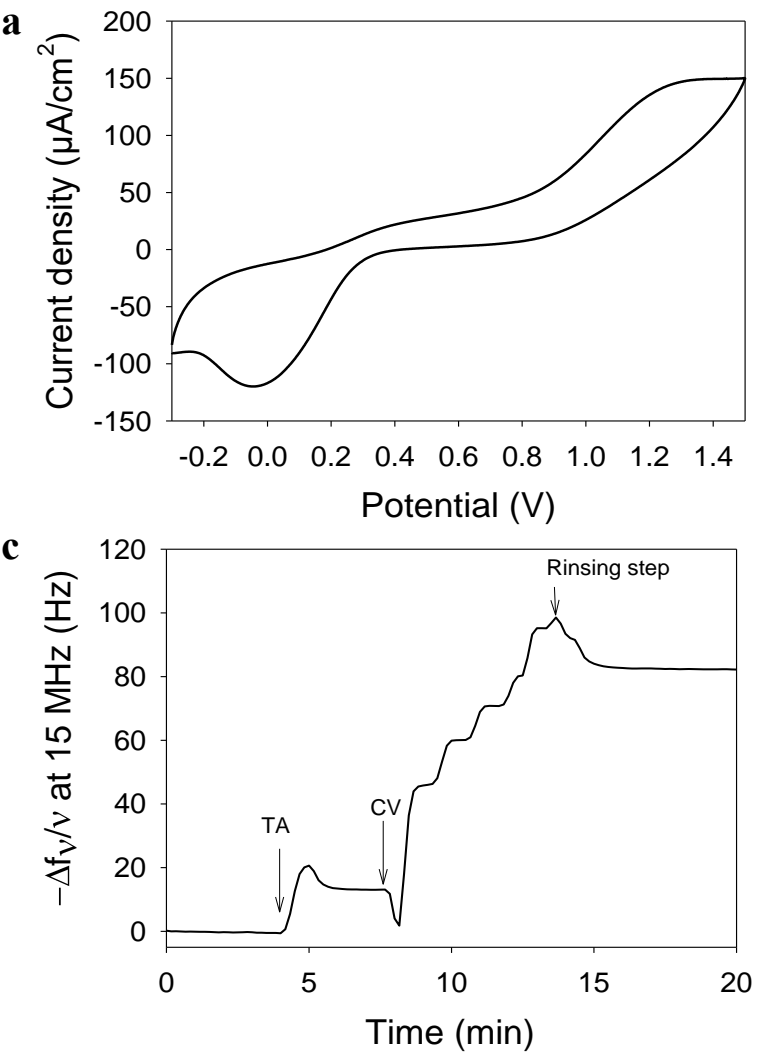

b

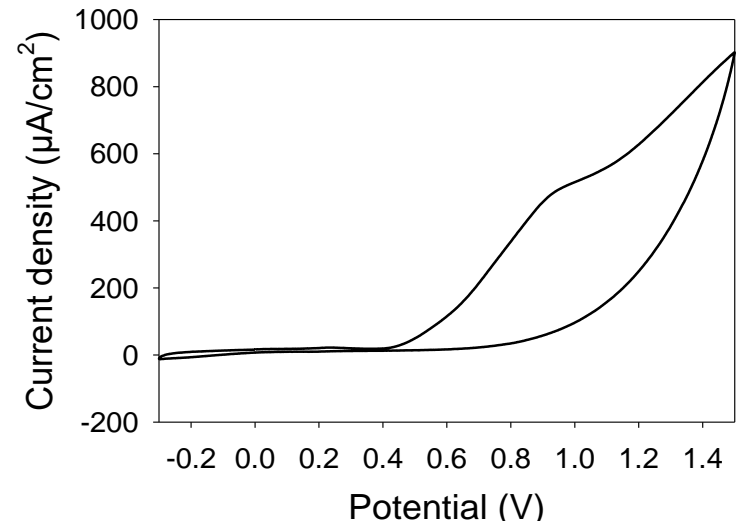

d

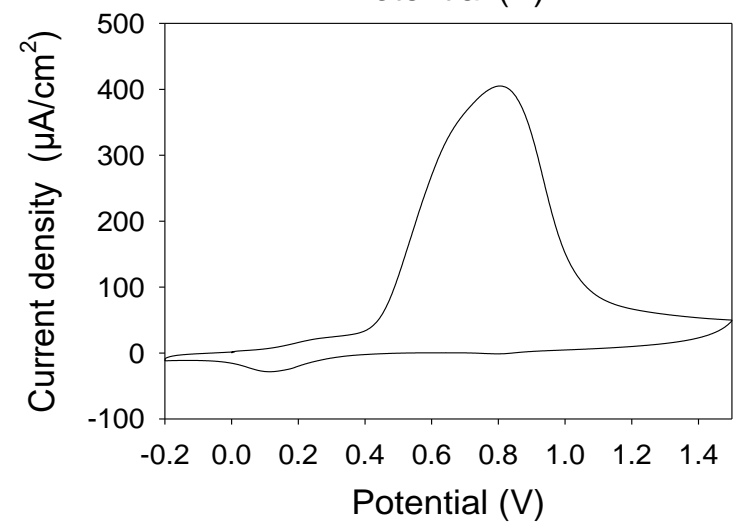

Figure 2: Cyclic voltammograms, obtained on ITO-QCM crystal, of (a) Fe(II) solution $\left(\mathrm{FeSO}_{4}\right.$, $1 \mathrm{mg} / \mathrm{mL})$ solution, (b) TA $(10 \mathrm{mg} / \mathrm{mL})$ at a scan rate of $50 \mathrm{mV} / \mathrm{s}$ with the (c) in-situ evolution of the normalized frequency shift, measured by QCM, as a function of time during the application of the cyclic voltammetry (d) Cyclic voltammogram of Fe(II)/TA mixture at 2.5 molar ratio at a scan rate of $50 \mathrm{mV} / \mathrm{s}$. The supporting electrolyte was $150 \mathrm{mM} \mathrm{KPF}_{6}$ buffer solution at $\mathrm{pH} 3$. 
The voltammogram of TA exhibits an oxidation peak at $0.93 \mathrm{~V}$ (Figure $2 \mathrm{~b}$ ). The reduction peak is lacking, meaning that the electrochemical reaction is irreversible as described in the literature..$^{55}$

Electrochemical coupled QCM was used to monitor in situ the evolution of the frequency shift related to the deposition of mass on the ITO-QCM crystal (working electrode) (Figure 2c). When TA solution was brought in contact with the ITO-QCM crystal, a small frequency shift $(18 \mathrm{~Hz})$ was observed corresponding to TA adsorption. Free polyphenolic (catechol and gallol) moieties of TA allows its adsorption on the surface of ITO $\left(\operatorname{In}_{2} \mathrm{O}_{3} / \mathrm{SnO}_{2}\right.$ metal oxide). Indeed, catechol and gallol based molecules are known to interact firmly with metal oxide materials as it was put in evidence for dopamine ${ }^{56}$ and catechol-modified molecules. ${ }^{27}$ The interaction mechanism of catechol and gallol moieties with metal oxides is based on their $\mathrm{OH}$ groups forming bidentate bonding with metal surface. ${ }^{57}$ An increase of the frequency shift is observed during the application of the cyclic voltammetry ( 5 cycles at $50 \mathrm{mV} / \mathrm{s})$. At the time when TA is irreversibly oxidized, a mass deposition is detected, which might originate from an electro-cross-linking of TA molecules, probably through aryloxy radical formation (Figure 2c). ${ }^{58}$ Similarly to the CV signal of $\mathrm{Fe}(\mathrm{II})$, the oxidation peak of TA on ITO was shifted compared to values reported in literature on gold electrode $(0.44 \mathrm{~V})$. Fe(II)/TA mixture showed a first peak of oxidation at 0.25 $\mathrm{V}$, attributed to $\mathrm{Fe}(\mathrm{II})$ oxidation, followed by a second larger peak at $0.80 \mathrm{~V}$, corresponding to galloyl oxidation (Figure 2d). A small reduction peak is visible at $0.12 \mathrm{~V}$, which can be assigned to $\mathrm{Fe}(\mathrm{III})$ reduction. According to the cyclic voltammograms, it can be anticipated that by working at potentials between 0.1 and $0.5 \mathrm{~V}$, the oxidation of $\mathrm{Fe}(\mathrm{II})$ to $\mathrm{Fe}(\mathrm{III})$ occurs while the oxidation of TA remains limited. 
Electro-triggered self-assembly of TA-Fe(III) films. In order to induce and to control the selfassembly, the gradient of morphogens, Fe(III), was generated at the electrode surface by electrochemical oxidation of Fe(II) induced galvanostatically. The applied current controls the amount of exchanged electrical charges and thus the quantity of morphogen generated at the working electrode. QCM was used to monitor in situ the self-assembly of TA-Fe(III) films during the application of a constant current with the ITO-QCM crystal acting as working electrode. When a $\mathrm{Fe}(\mathrm{II}) / \mathrm{TA}$ solution (2.5 Fe(II)/TA molar ratio at $\mathrm{pH} 3$ ) was brought in contact with the ITO-QCM crystal, a small frequency shift $(20 \mathrm{~Hz})$ is observed corresponding to TA adsorption (Figure S-1 in SI). As soon as a current density of $6.25 \mu \mathrm{A} / \mathrm{cm}^{2}$ is applied, the normalized frequency shift increases, in first approximation, linearly with time indicating a mass deposition (Figure 3a).
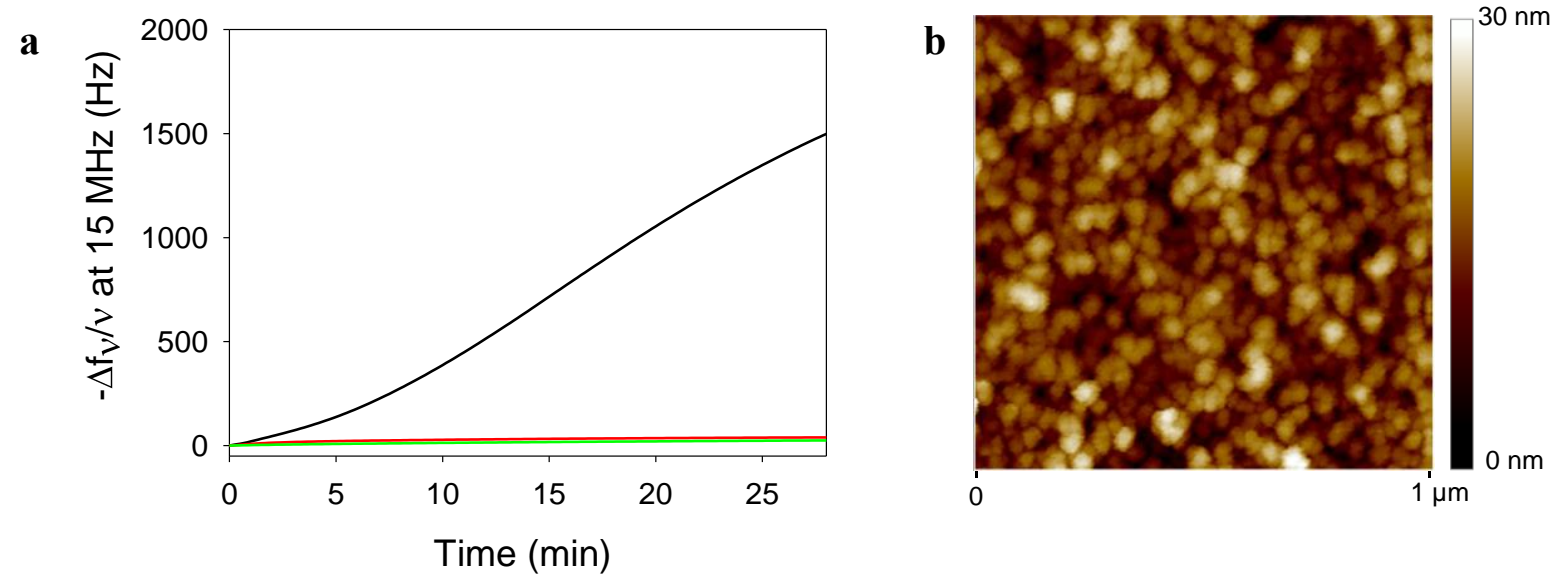

Figure 3: (a) Evolution of the normalized frequency shift, measured by QCM, as a function of time of (black line) Fe(II)/TA mixture (2.5 Fe(II)/TA molar ratio at pH 3), (red line) $\mathrm{Fe}(\mathrm{II})$ and (green line) TA solutions during the application of $6.25 \mu \mathrm{A} / \mathrm{cm}^{2}$. (b) Typical AFM image, obtained in contact mode and liquid state, of self-assembled TA-Fe(III) film obtained after 30 $\min$. 
When the application of the current is interrupted after $30 \mathrm{~min}$ and followed by a rinsing step, the evolution of the resonance frequency is stabilized at around $1500 \mathrm{~Hz}$ (Figure S-1 in SI). In the sole presence of TA or Fe(II), smaller frequency shifts (less than $30 \mathrm{~Hz}$ ) were observed (Figure 3a). The presence of both partners, Fe(II) and TA, is thus required which strongly indicates the self-assembly of a TA-Fe(III) film.

The morphology of the deposited film was characterized by AFM in contact mode and liquid state. Figure $3 b$ shows a typical topography corresponding to a TA-Fe(III) film self-assembled for $30 \mathrm{~min}$ with an applied current of $6.25 \mu \mathrm{A} / \mathrm{cm}^{2}$. The film appeared grainy with a roughness (RMS calculated on $10 \times 10 \mu \mathrm{m}^{2}$ AFM images) of about $5.2 \pm 1 \mathrm{~nm}$. The film consisted in a homogeneous assembly of $30 \mathrm{~nm}$-diameter nanoparticles (Figure 3b). 
a

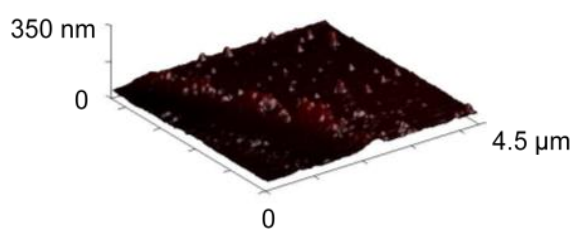

b $350 \mathrm{~nm}$

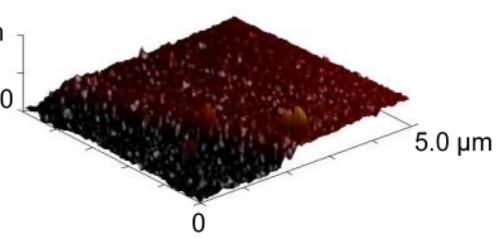

c $\quad 350 \mathrm{~nm}$
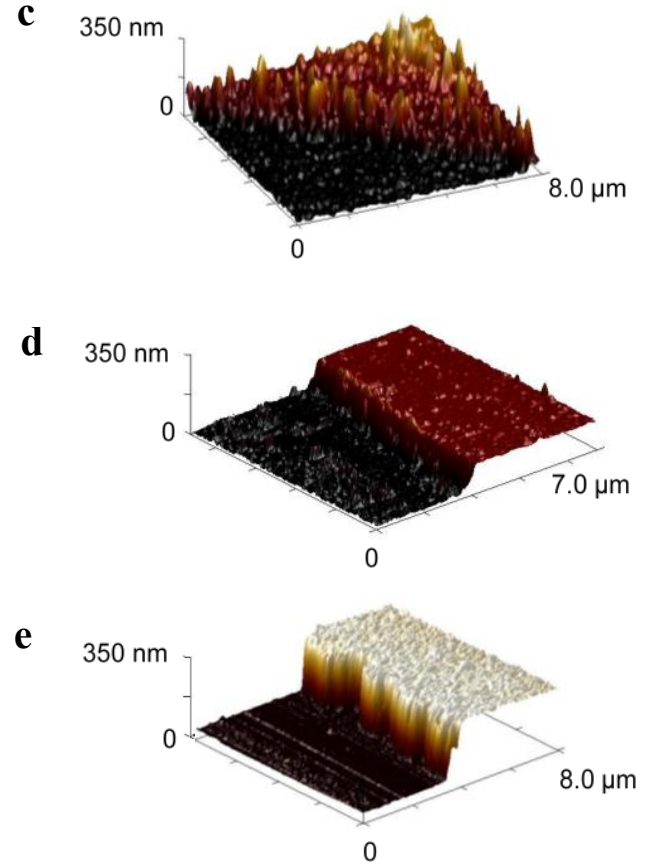
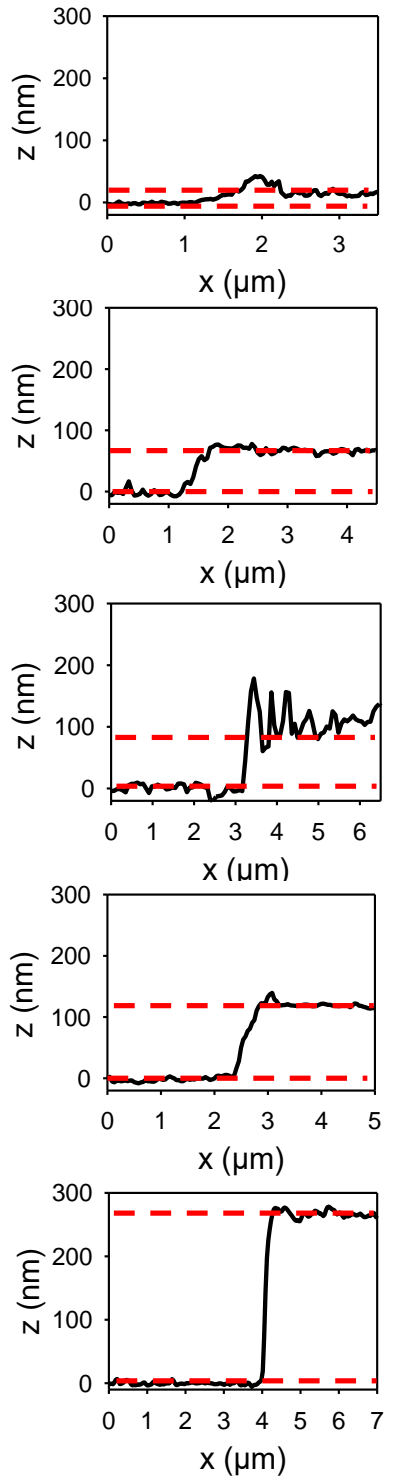

Figure 4: Typical AFM 3D images, obtained in contact mode and liquid state, and respective cross-section profiles of a scratched TA-Fe(III) film, obtained after (a) 5 min, (b) 10 min, (c) 20 min, (d) $30 \mathrm{~min}$ and (e) $70 \mathrm{~min}$ of self-assembly with TA/Fe(II) solution (2.5 Fe(II)/TA molar ratio molar at $\mathrm{pH} \mathrm{3)}$ at an applied current of $6.25 \mu \mathrm{A} / \mathrm{cm}^{2}$. The red lines indicate the bare substrate and the surface of the film which the distance represents the film thickness.

It is interesting to compare this result to the films obtained by Ejima et al. in a one pot process in alkaline solution of TA-Fe(III). At similar iron ions/TA molar ratio, the roughness of electrogenerated TA-Fe(III) self-assembled films is similar to the one obtained by Ejima et al.. ${ }^{5}$ 
The film thickness was determined at different buildup time (application time of the current density) by AFM after scratching (Figure 4).

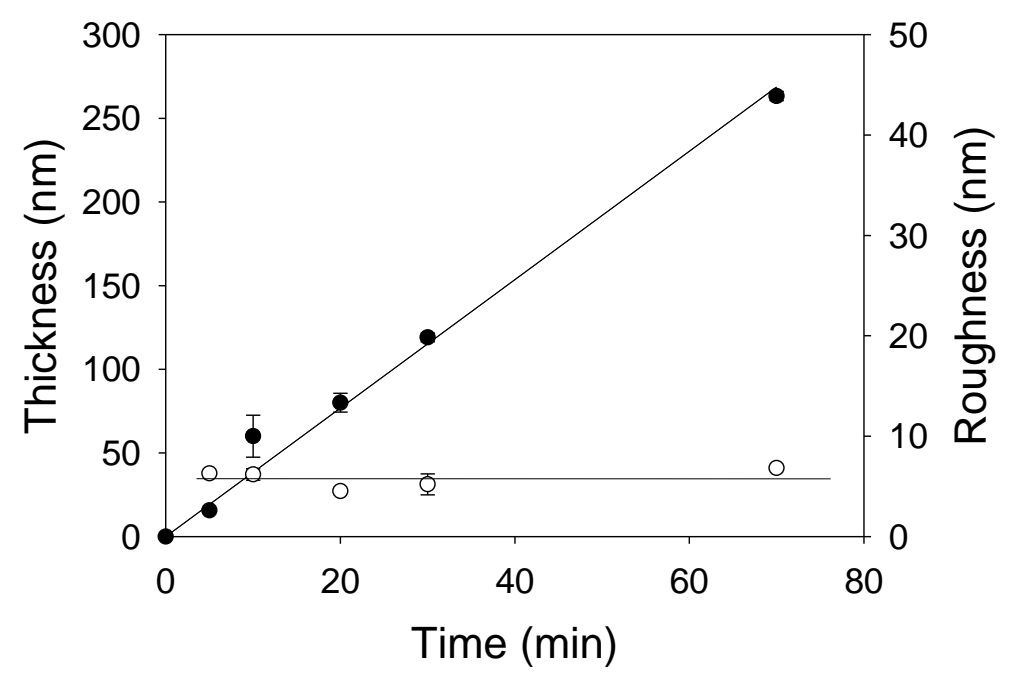

Figure 5: Evolution of the thickness $(\Theta)$ and the roughness $(\bigcirc)$, measured by AFM in contact mode and in liquid state, of TA-Fe(III) film as a function of self-assembly time with $\mathrm{TA} / \mathrm{Fe}$ (II) mixture solution (2.5 Fe(II)/TA molar ratio at $\mathrm{pH}$ 3) at an applied current of $6.25 \mu \mathrm{A} / \mathrm{cm}^{2}$. The film roughness was calculated on topographic $10 \times 10 \mu \mathrm{m}^{2} \mathrm{AFM}$ images. The data represent the mean and the standard deviation of three measurements performed on three independent samples. Lines are used to guide the eye.

After 5 min of self-assembly, the film covers uniformly the whole substrate with a thickness of $16 \pm 1 \mathrm{~nm}$ and a roughness of $6.3 \pm 0.1 \mathrm{~nm}$. The film thickness increases as a function of the selfassembly time until $263 \pm 3 \mathrm{~nm}$ reached after $70 \mathrm{~min}$. It can be noticed that the film roughness remains almost constant reaching $6.8 \pm 0.1 \mathrm{~nm}$ (Figure 5). The constant roughness is probably due to the continuous self-assembly of TA-Fe(III) complexes, in the vicinity of the electrode, 
which adsorb on the surface along the process. TA-Fe(III) film thickness is simply tuned by adjusting the time over which the potential is applied.

Water contact angle measurements were performed to determine the surface wettability before and after TA-Fe(III) self-assembly on ITO-QCM crystal. Before film buildup, ITO-QCM crystals were treated by UV-ozone for $15 \mathrm{~min}$. This treatment decreases the surface contact angle from $104.2 \pm 1.3^{\circ}$ to $21.3 \pm 2.5^{\circ}$. After TA-Fe(III) self-assembly on UV-ozone treated ITO-QCM crystal, the contact angle slightly increases to $24.6 \pm 6^{\circ}$. This result is in agreement with the results obtained on TA-Fe(III) layer-by-layer films. ${ }^{59}$

Chemical analysis of the self-assembled TA-Fe(III) film. XPS investigation allowed the determination of both atomic and chemical functions composition of the self-assembled films. Following atoms were detected in the XPS spectrum of TA-Fe(III) self-assembled film: carbon (C), oxygen (O) and iron (Fe) (Figure 6a-b). Representing 70\% of the elemental composition, the C 1s peak at $285 \mathrm{eV}$ (used as an internal calibration peak) confirmed the presence of TA, the only carbon-containing compound present in the starting TA/Fe(II) solution. The position of Fe $2 \mathrm{p}_{1 / 2}$ and $\mathrm{Fe} 2 \mathrm{p}_{3 / 2}$ peaks, centered at $725.5 \mathrm{eV}$ and $711.9 \mathrm{eV}$ respectively, indicated the presence of Fe(III) species in the self-assembled film (Figure 6c). ${ }^{60}$ 


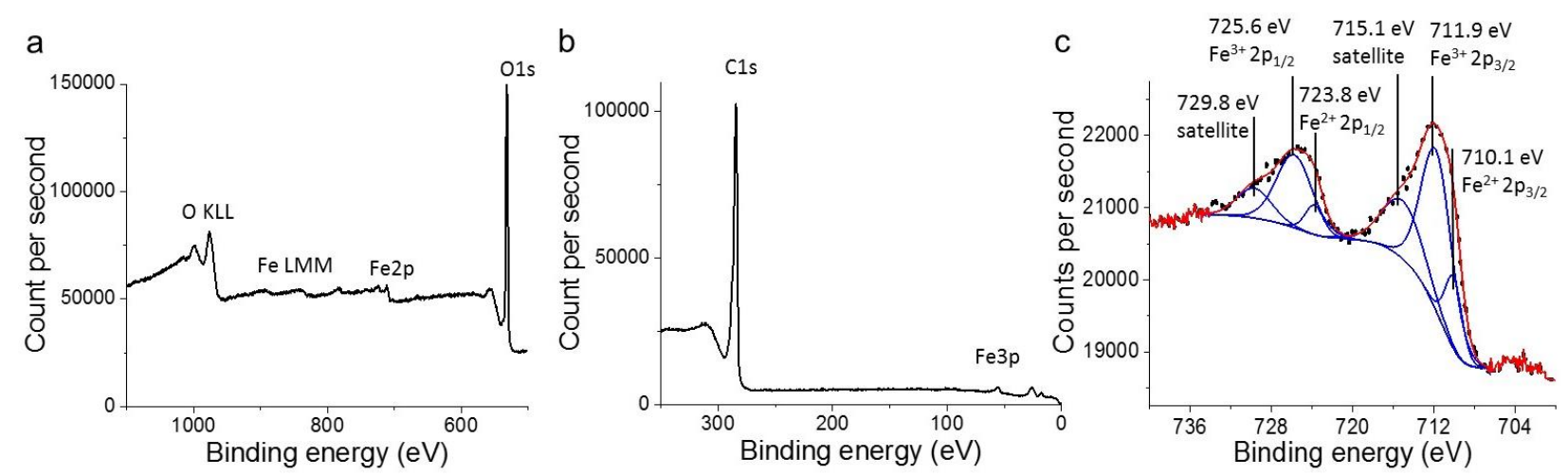

Figure 6: XPS $(a, b)$ survey and (c) Fe 2p core-level spectra of TA-Fe(III) self-assembled film, with $\mathrm{TA} / \mathrm{Fe}(\mathrm{II})$ mixture solution (2.5 $\mathrm{Fe}(\mathrm{II}) / \mathrm{TA}$ molar ratio at $\mathrm{pH} 3$ ) after $30 \mathrm{~min}$ at an applied current of $6.25 \mu \mathrm{A} / \mathrm{cm}^{2}$. Experimental data are drawn in dotted black line.

By decomposition of both peaks, the relative proportion of $\mathrm{Fe}(\mathrm{III})$ and $\mathrm{Fe}(\mathrm{II})$ were evaluated at $80 \%$ and $20 \%$, respectively. These values of $\mathrm{Fe}(\mathrm{III}) / \mathrm{Fe}(\mathrm{II})$ ratio were in agreement with the decomposition of Fe 3p peak observed at $56.8 \mathrm{eV}$ (Figure 7a). The presence of Fe(III) in major proportion validates our proposed model of film buildup based on the gradient of Fe(III) generated in situ from the electrode surface. The presence of $\mathrm{Fe}(\mathrm{II})$ is due to its interaction with gallic and catecholic moities of TA (as mono-complex). ${ }^{49}$ In addition by decomposition of the O1s signal of TA-Fe(III) film, two peaks are obtained: the peak centered at $533.5 \mathrm{eV}$ is attributed to $\mathrm{HO}-\mathrm{C}$ groups of TA and Ho-Fe species and the peak centered at $531.8 \mathrm{eV}$ is attributed to $\underline{\mathrm{O}}=\mathrm{C}$ groups of TA and $\underline{\mathrm{O}}-\mathrm{Fe}$ species, ascribed to $\underline{\mathrm{O}}-\mathrm{C}$ interacting with $\mathrm{Fe}(\mathrm{III})$ (Figure $7 \mathrm{~b}$ ). If we consider pure TA, the peak at $533.5 \mathrm{eV}$ (Ho-C groups) is relatively bigger in comparison to the peak at $531.8 \mathrm{eV}(\underline{\mathrm{O}}=\mathrm{C}$ groups $)$ (Figure $\mathrm{S}-2$ in $\mathrm{SI}) .{ }^{60}$ Then, the $\mathrm{C}-\mathrm{O}$ bonds of TA are affected by the presence of $\mathrm{Fe}(\mathrm{III})$ resulting in the decrease of the relative fraction of peak Ho- $-\mathrm{C}$ and the increase of the peak at $531.8 \mathrm{eV} .{ }^{61}$ This result put in evidence the coordination between Fe(III) and TA through phenol groups from gallic units, as previously reported in the literature. ${ }^{36,62}$ The atomic Fe/TA ratio was calculated using $\mathrm{C}_{76} \mathrm{H}_{52} \mathrm{O}_{46}$ as chemical formula of TA. By integration of 
the elemental peaks of $\mathrm{Fe}$ and $\mathrm{C}$ (with respect to their individual sensitivity factors), we obtain a Fe/TA ratio of about 1:2 which corresponds to bis-coordinated complexes ( $1 \mathrm{Fe}$ complexed by 2 TA). Deconvolution of the C $1 \mathrm{~s}$ peak located in the area going from $283 \mathrm{eV}$ to $294 \mathrm{eV}$ gives access to the relative proportion of carbons involved in both $\underline{\mathrm{C}}-\mathrm{OH}$ and $\underline{\mathrm{C}}=\mathrm{O}$ groups (Figure $\mathrm{S}-2$ in SI). The carbon atom involved in the $\underline{\mathrm{C}}-\mathrm{OH}$ group is assigned to both phenol groups and to all six carbons constituting the glucose central ring of $\mathrm{TA}$. The other $\mathrm{C}=\mathrm{O}$ carbon included the carbonyl moiety coming from ester groups bonding of gallic acid units to form TA. According to the chemical structure of TA displayed in Figure 1a, the theoretical atomic ratio $\underline{\mathrm{C}}-\mathrm{O} / \underline{\mathrm{C}}=\mathrm{O}$ is 3.60, a value close to the experimental ratio of 3.55 that we measured on pure TA powder by XPS (Figure S-2 in SI).
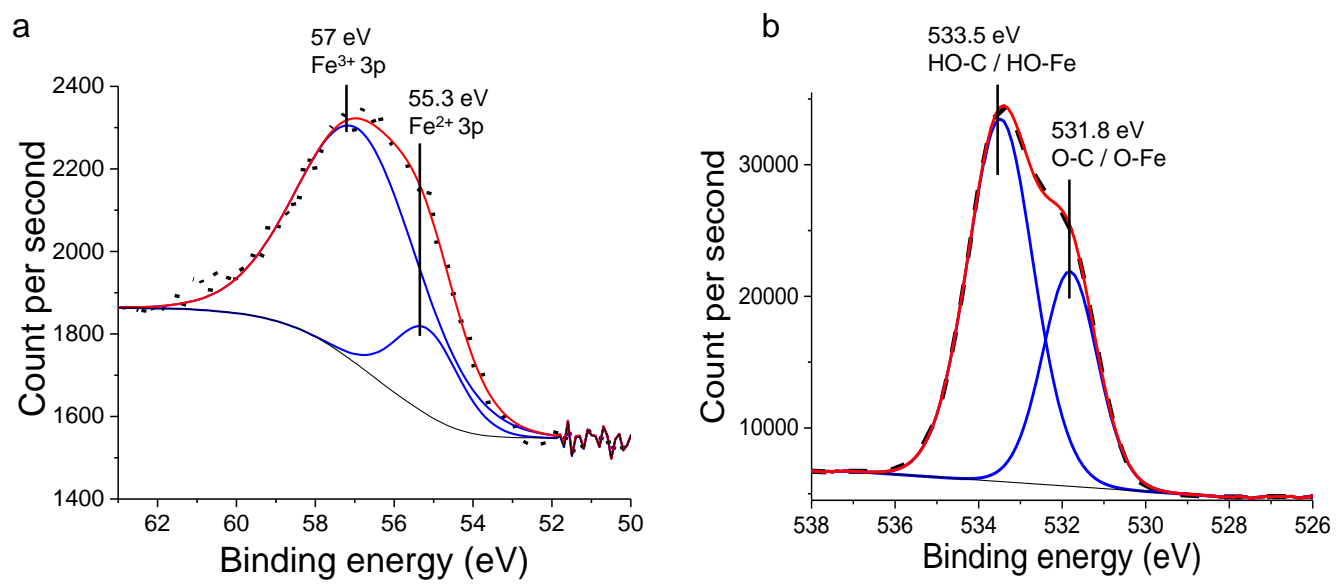

Figure 7: XPS (a) Fe 3p and (b) O 1s core-level spectra of TA-Fe(III) self-assembled film, with $\mathrm{TA} / \mathrm{Fe}(\mathrm{II})$ mixture solution (2.5 $\mathrm{Fe}(\mathrm{II}) / \mathrm{TA}$ molar ratio at $\mathrm{pH} 3$ ) after $30 \mathrm{~min}$ at an applied current of $6.25 \mu \mathrm{A} / \mathrm{cm}^{2}$. Experimental data are drawn in dotted black line. 
Surprisingly, XPS analysis of TA-Fe(III) self-assembled film leads to an atomic ratio $\underline{\mathrm{C}}-\mathrm{O} / \underline{\mathrm{C}}=\mathrm{O}$ of 2.80, a value indicating a higher proportion of $\underline{\mathrm{C}}=\mathrm{O}$ compared to $\underline{\mathrm{C}}-\mathrm{O}$. The presence of more $\mathrm{C}=\mathrm{O}$ groups than expected can be explained by the oxidation of some phenol groups into quinones due to either the current applied to self-assemble the film or to the oxygen of air, iron ions acting as catalysts. ${ }^{63}$ It is interesting to note that polyphenol-based coatings such as polydopamine films always contain a small proportion (20-30\%) of stable quinone groups in their architecture coming from the oxidation of phenols. ${ }^{64}$

Influence of the physico-chemical conditions on the self-assembly. To gain more mechanistic insight into the self-assembly process, several parameters that might influence the buildup process were varied. The current intensity was varied from 1.25 to $31.25 \mu \mathrm{A} / \mathrm{cm}^{2}$ while keeping the $\mathrm{pH}$ of the building solution at 3. It came out that the TA-Fe(III) film self-assembly kinetic strongly depends on the applied current: higher current intensities lead to faster buildup kinetics (Figure 8a). A higher current intensity leads to a higher quantity of electrogenerated Fe(III) ions, the morphogen, in the vicinity of the working electrode leading to the assembly of more quantity of TA molecules on the surface and thus making the film thicker. A levelling off of TA-Fe(III) self-assembly occurs at a certain time depending on the applied current (Figure 8a-b). Figure 8c$d$ shows the evolution of the potential during the application of the different applied currents. An effective self-assembly of TA-Fe(III) film is observed until a threshold value below $0.6 \mathrm{~V}$. Above this value, the buildup of TA-Fe(III) film slows down until a plateau is reached. We fixed an upper limit of $1.2 \mathrm{~V}$ for the potential where the current was switched off. During the buildup, a shift of the applied potential toward more oxidative conditions occurs so that the current in the system remains constant. Below a potential of $0.6 \mathrm{~V}$, the current is mostly dedicated to oxidize $\mathrm{Fe}(\mathrm{II})$ into $\mathrm{Fe}(\mathrm{III})$ and thus fully supporting the self-assembly of the film. However for current 
densities above $6.25 \mu \mathrm{A} / \mathrm{cm}^{2}$, maintaining a constant current density during the buildup results in an increase of the potential above $0.6 \mathrm{~V}$. This triggers the oxidation of TA molecules, and their subsequent crosslinking on the surface of the electrode (Figure 2b-c). ${ }^{65-66}$ The cross-linked TA film limits the diffusion of iron ions towards and from the electrode, slowing down the selfassembly. Interestingly before reaching the blocking plateau, thicker films are formed with slower self-assembly kinetics, i.e. with lower current densities. This result suggests that the electronic transfer becomes less favorable while the film growth probably because the masstransfer of $\mathrm{Fe}(\mathrm{II})$ to the electrode is too slow. 

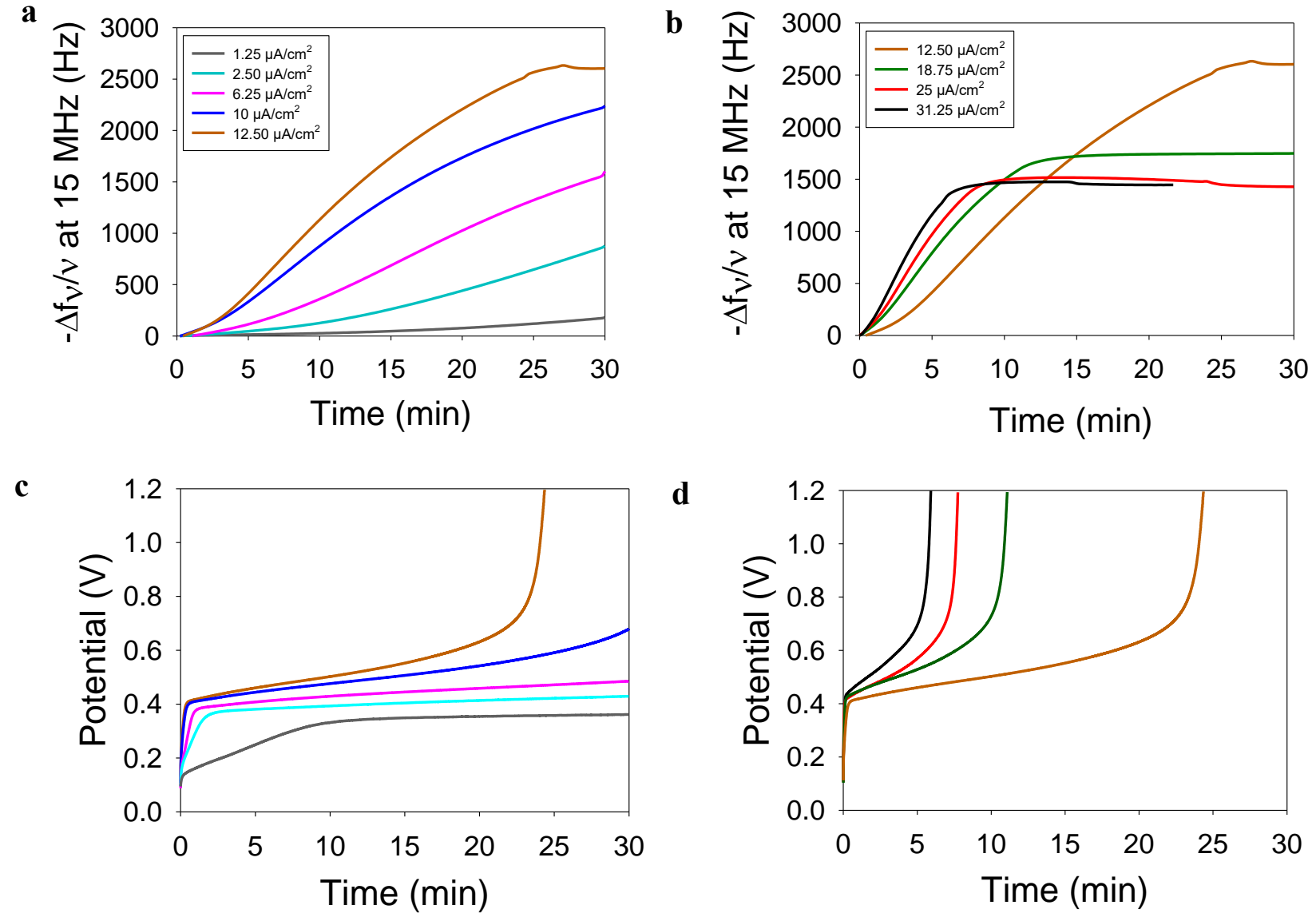

Figure 8: $(a, b)$ Evolution of the normalized frequency shift, measured by QCM, and (c, d) of the potential as a function of time during the self-assembly of TA-Fe(III) film performed at different current intensities with $\mathrm{TA} / \mathrm{Fe}(\mathrm{II})$ mixture (2.5 Fe(II)/TA molar ratio at $\mathrm{pH} 3)$.

To evaluate the influence of TA oxidation on the morphology of the film, the self-assembly of TA/Fe(II) mixture (2.5 Fe(II)/TA molar ratio at $\mathrm{pH} 3$ ) was performed by applying a potential of $0.8 \mathrm{~V}$ for $30 \mathrm{~min}$, favoring simultaneously the oxidation of TA and Fe(II) (Figure S-3 in SI). The obtained film showed a roughness of $18 \mathrm{~nm}$ with a thickness of $200 \mathrm{~nm}$. The cross-linking of TA, due to its oxidation, induces an increased roughness of the self-assembled film. The coordination between TA and $\mathrm{Fe}(\mathrm{III})$ is $\mathrm{pH}$-dependent leading to mono-complex at $\mathrm{pH}<2$, dicomplex at $3<\mathrm{pH}<6$ and tris-complex at $\mathrm{pH}>7 .{ }^{5}$ The influence of the $\mathrm{pH}$ and the $\mathrm{Fe}(\mathrm{II}) / \mathrm{TA}$ molar ratio of the building solution were also investigated for a fixed applied current of 6.25 
$\mu \mathrm{A} / \mathrm{cm}^{2}$ (Figure 9). Below $\mathrm{pH} 3$ with $\mathrm{Fe}(\mathrm{II}) / \mathrm{TA}$ molar ratio of 2.5, a small buildup is obtained (about $25 \mathrm{~Hz}$ after 30 min of self-assembly). The electrogeneration of $\mathrm{Fe}(\mathrm{III})$ did not lead to an effective film self-assembly due to the formation of mono-complexes mainly.
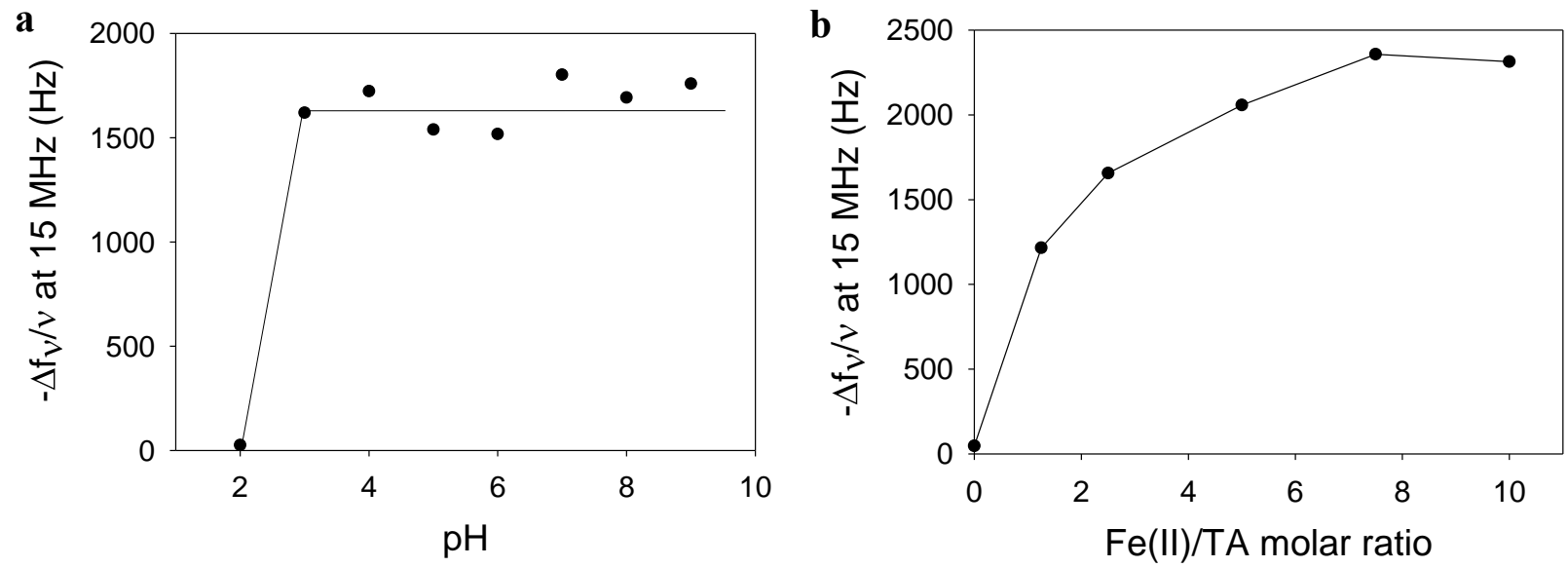

Figure 9: Normalized frequency shift, measured by QCM, of self-assembled TA-Fe(III) film as function (a) of the buildup $\mathrm{pH}$, with $2.5 \mathrm{Fe}(\mathrm{II}) / \mathrm{TA}$ molar ratio and (b) of $\mathrm{Fe}(\mathrm{II}) / \mathrm{TA}$ molar ratio, with a buildup $\mathrm{pH}$ of 3 . The applied current was fixed at $6.25 \mu \mathrm{A} / \mathrm{cm}^{2}$ for $30 \mathrm{~min}$.

Above $\mathrm{pH} 3$, there is no influence of the $\mathrm{pH}$ on the buildup (Figure 9a). At high $\mathrm{pH}$, it is known that three gallic moieties can interact with one Fe(III) ion to form a stable octahedral complex. ${ }^{67}$ We thus performed XPS analysis of TA-Fe(III) films obtained at pH 9 (Figure S-5 in SI). In contrast to the ones built at $\mathrm{pH} 3$, films built at $\mathrm{pH} 9$ have a Fe/TA ratio about 1:2.7, close to triscoordinated complexes ratio ( $1 \mathrm{Fe}$ complexed by $3 \mathrm{TA}$ ). The atomic ratio $\underline{\mathrm{C}}-\mathrm{O} / \underline{\mathrm{C}}=\mathrm{O}$ is about of 2.74 (close to the one obtained for a film built at $\mathrm{pH} 3$ ). High buildup $\mathrm{pH}$ favors tris-complexes formation without changing the buildup kinetic. 
Then, keeping fixed the applied current density $\left(6.25 \mu \mathrm{A} / \mathrm{cm}^{2}\right)$ and the buildup $\mathrm{pH}$ at 3 , $\mathrm{Fe}(\mathrm{II}) / \mathrm{TA}$ molar ratio was varied from 0 to 10 with TA concentration fixed at $10 \mathrm{mg} / \mathrm{mL}$. After 30 min of self-assembly, thicker TA-Fe(III) films were obtained with higher Fe(II)/TA molar ratios, reaching a plateau for a $\mathrm{Fe}(\mathrm{II}) / \mathrm{TA}$ molar ratio of 8 (Figure 9b). We performed XPS measurements on three different self-assembled films obtained with Fe(II)/TA molar ratios of $0.5,2.5$ and 10 in the building mixture at $\mathrm{pH} 3$. Whatever the $\mathrm{Fe}(\mathrm{II}) / \mathrm{TA}$ molar ratio of the mixture, Fe/TA molar ratio of the self-assembled film is about $1: 2$, corresponding to biscomplexes (data not shown). The relative percentages of Fe(III) and Fe(II) are similar (about 80:20) for films obtained with $\mathrm{Fe}(\mathrm{II}) / \mathrm{TA}$ molar ratio of 0.5 and 2.5. An increased proportion of $\mathrm{Fe}(\mathrm{III})$ (with a $\mathrm{Fe}(\mathrm{III}) / \mathrm{Fe}$ (II) ratio of 90/10) was obtained for films built with $\mathrm{Fe}(\mathrm{II}) / \mathrm{TA}$ molar ratio of 10. By applying a fixed current density and increasing Fe(II)/TA building molar ratio, the same quantity of $\mathrm{Fe}(\mathrm{III})$ is electrogenerated in the solution and the same $\mathrm{Fe} / \mathrm{TA}$ molar ratio is obtained in the films. However, the kinetic of the self-assembly increases with Fe(II)/TA molar ratio (Figure S-6 in SI), with higher proportion of incorporated Fe(III) ions. In the building solution, monomeric $\mathrm{Fe}(\mathrm{II}) / \mathrm{TA}$ complexes are formed. Taking into account the molecular formulae of TA, 10 moieties ( 5 gallic and 5 catecholic moities) per TA molecule can be monocomplexed with $\mathrm{Fe}(\mathrm{II})$. By increasing the $\mathrm{Fe}(\mathrm{II}) / \mathrm{TA}$ molar ratio in the building solution, each molecule of TA is complexed with an increasing number of $\mathrm{Fe}(\mathrm{II})$ ions until saturation $(\mathrm{Fe}(\mathrm{II}) / \mathrm{TA}=10)$. At the saturation, all $\mathrm{TA}$ molecules in contact with the electrode are surrounded by $10 \mathrm{Fe}(\mathrm{II})$ ions which increases the probability of electro-generating $\mathrm{Fe}(\mathrm{III})$ ions prone to interact with two TA molecules. These experiments highlight the crucial role of $\mathrm{Fe}(\mathrm{II}) / \mathrm{TA}$ molar ratio on the self-assembly of the film. 
Stability of the coating. To test the stability of TA-Fe(III) self-assembled films, EDTA solutions, known to chelate metal cations, were put in contact under a flow rate of $600 \mu \mathrm{L} / \mathrm{min}$ with the films built at two different $\mathrm{pHs}$ : $\mathrm{pH} 3$ and $\mathrm{pH}$ 7.4. The $\mathrm{pH}$ of the EDTA solution was prepared in $150 \mathrm{mM} \mathrm{KPF}_{6}$ fixed at the same $\mathrm{pH}$ of the film building solution. We found previously that the same mass is deposited on the electrode at these two pHs (Figure 9a). After 80 min of contact with EDTA at pH 3,87\% of TA-Fe(III) film, self-assembled at pH 3, is lost (Figure 10a). In contrast when the film is self-assembled at pH 7.4 and put in contact with EDTA solution at $\mathrm{pH} 7.4$, the film is stable. There is no loss of mass.
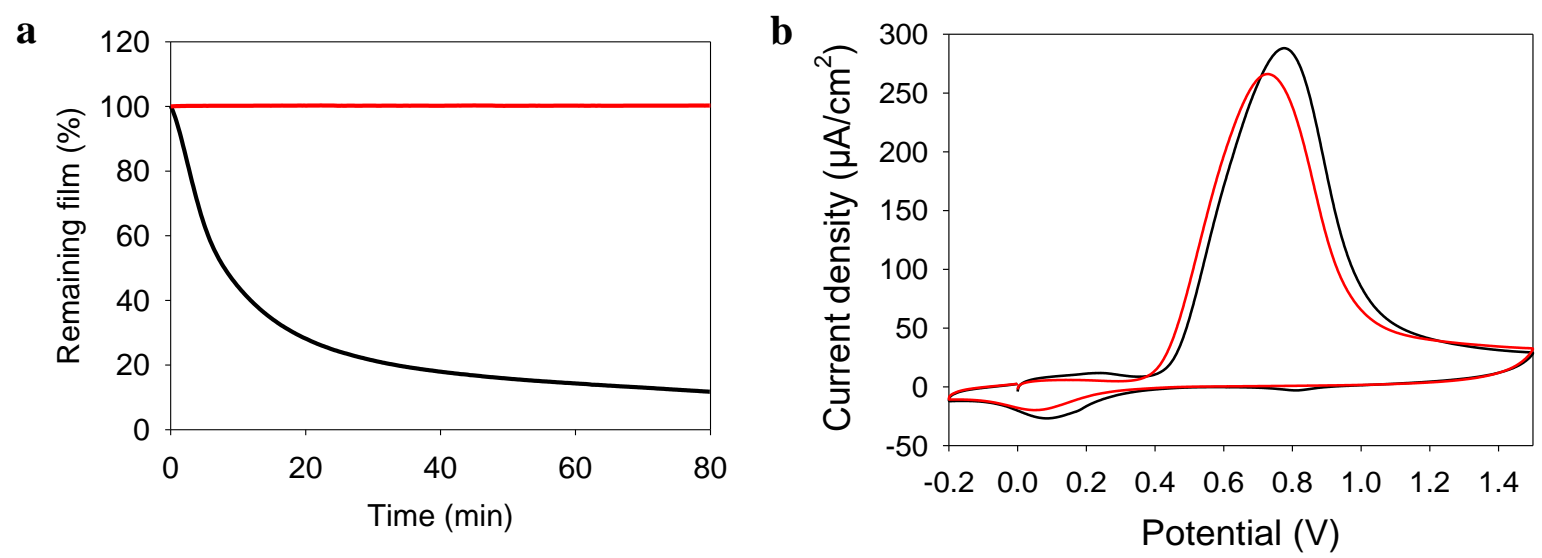

Figure 10: (a) Evolution of the remaining TA-Fe(III) films, self-assembled at (black curve) pH 3 and (red curve) $\mathrm{pH} 7.4$, as a function of time during the contact with $100 \mathrm{mM}$ EDTA, prepared in $150 \mathrm{mM} \mathrm{KPF}_{6}$ at the same $\mathrm{pH}$. (b) First cycle of the cyclic voltamogramm, performed after buildup in $150 \mathrm{mM} \mathrm{KPF}_{6}$ solution at $50 \mathrm{mV} / \mathrm{s}$, of TA-Fe(III) films self-assembled (black curve) at $\mathrm{pH} 3$ and (red curve) at $\mathrm{pH} 7.4$, with $2.5 \mathrm{Fe}(\mathrm{II}) / \mathrm{TA}$ molar ratio mixture solution for $30 \mathrm{~min}$ at an applied current of $6.25 \mu \mathrm{A} / \mathrm{cm}^{2}$. 
TA-Fe(III) film is thus more stable when self-assembled at $\mathrm{pH} 7.4$ than at $\mathrm{pH} 3$. This is consistent with the fact that the number of coordination bonds increases with the $\mathrm{pH}$ leading to more stable TA-Fe(III) complexes. ${ }^{5}$ When a cyclic voltammetry was performed on TA-Fe(III) self-assembled films at $\mathrm{pH} 3$ and $\mathrm{pH}$ 7.4, a similar irreversible oxidation peak of TA (between 0.7 and $0.8 \mathrm{~V}$ ) was observed with more visible iron redox peaks (at $0.2 \mathrm{~V}$ and $0.1 \mathrm{~V}$ ) at $\mathrm{pH} 3$ than at $\mathrm{pH} 7.4$ (Figure 10b). Self-assembly of TA-Fe(III) at pH 7.4 leads to more coordinated and thus less electro-sensitive Fe(III) ions than at $\mathrm{pH}$ 3. Indeed, mono-coordinated complexes of catecholic and gallic moieties can be involved in electron transfer reactions in contrast to di- or tris-coordinated complexes that prevent redox reactions. ${ }^{68}$
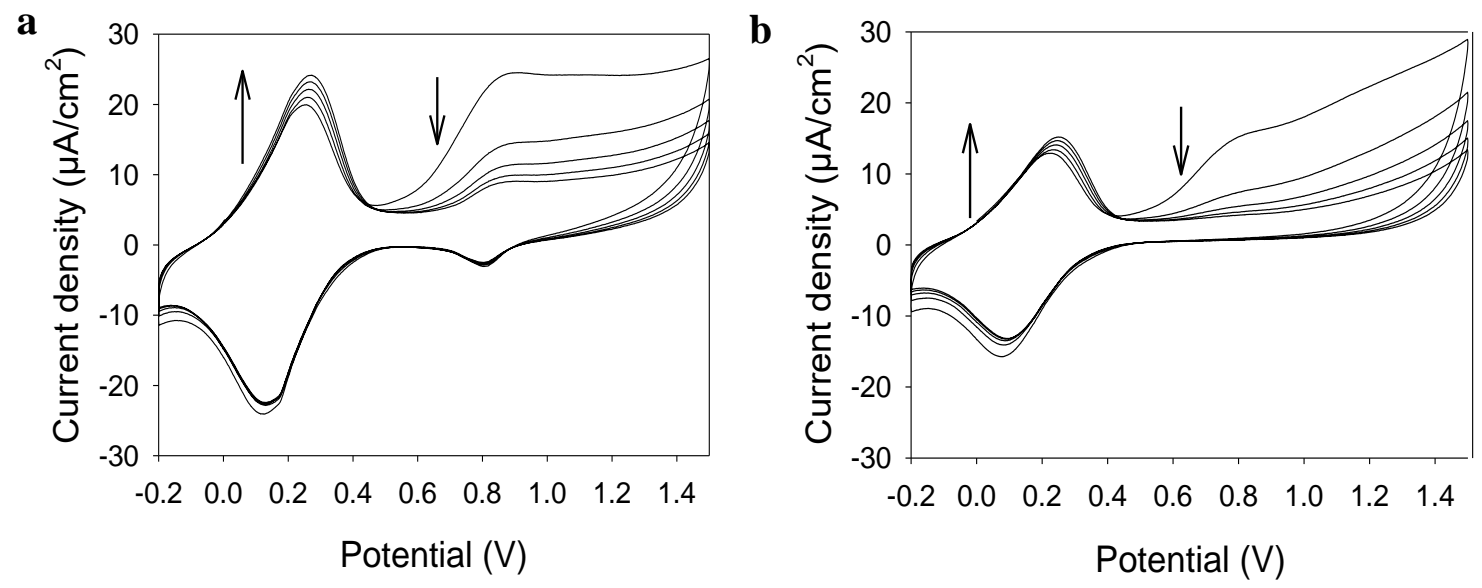

Figure 11: Cyclic voltamogramms of TA-Fe(III) films, performed in contact with $150 \mathrm{mM} \mathrm{KPF}_{6}$ solution at $50 \mathrm{mV} / \mathrm{s}$, after buildup at (a) $\mathrm{pH} 3$ and (b) $\mathrm{pH}$ 7.4. The black arrows indicate the evolution of the signal during the cyclic voltammetry. The self-assembled films were obtained with $\mathrm{TA} / \mathrm{Fe}$ (II) mixture solution $(2.5 \mathrm{Fe}(\mathrm{II}) / \mathrm{TA}$ molar ratio at $\mathrm{pH} 3$ and 7.4 , respectively) at an applied current of $6.25 \mu \mathrm{A} / \mathrm{cm}^{2}$ for $30 \mathrm{~min}$.

The stability of TA-Fe(III) coating was also tested by the application of reductive potentials to induce the reduction of Fe(III) into Fe(II) (Figure S-7 in SI). No visible dissolution of the film 
was observed at $-0.4 \mathrm{~V}$ indicating the stability of TA-Fe(III) complexes. To go further, several cycles of cyclic voltammetry have been applied on TA-Fe(III) self-assembled films at pH 7.4 and 3 (Figure 11). After the first cycle, the oxidation peak of TA decreases about 10 fold followed by a slower continuous decrease during the following cycles. This indicates an irreversible TA oxidation, probably at the vicinity of the electrode. At the same time, the oxidoreduction signal of $\mathrm{Fe}(\mathrm{II}) / \mathrm{Fe}(\mathrm{III})$ increases. This can be explained by the release of $\mathrm{Fe}(\mathrm{III})$ from di-coordinated complexes simultaneously with the irreversible oxidation of gallic moieties of TA. The oxidation of TA seems to be partially reversible at $\mathrm{pH} 3$ (presence of a reduction peak of TA at $0.8 \mathrm{~V}$ ) in comparison to $\mathrm{pH} 7.4$. During the application of the cyclic voltammetry, a small increase of the frequency shift is observed probably due to the reorganization of the film (data not shown). The stability of the film towards $\mathrm{pH}$ changes was also tested by increasing the $\mathrm{pH}$ from $\mathrm{pH} 3$ to $\mathrm{pH} 12$. After buildup of $\mathrm{TA} / \mathrm{Fe}(\mathrm{III})$ coating at $\mathrm{pH} 3$ and a rinsing step with 150 $\mathrm{mM} \mathrm{KPF}_{6}$ at $\mathrm{pH} 3$, a solution of $150 \mathrm{mM} \mathrm{KPF}_{6}$ at $\mathrm{pH} 12$ is put in contact with the film. The normalized frequency shift, related to the adsorbed mass, increases from 1500 to $2000 \mathrm{~Hz}$ in a reversible manner (Figure S-8a in SI). Indeed, when the $\mathrm{pH}$ is decreased back to $\mathrm{pH} 3$, the signal decreased back to $1500 \mathrm{~Hz}$. AFM images were performed on the obtained film at $\mathrm{pH} 3$ and at $\mathrm{pH}$ 12 (Figure S-8b-c in SI). By increasing the $\mathrm{pH}$, the thickness of the film increases from 120 to $140 \mathrm{~nm}$ with no change on the roughness. Finally, two other polyphenols, gallic acid and rosmarinic acid, were used mixed with $\mathrm{Fe}(\mathrm{II})$ ions to self-assemble a film using the electrochemical stimulus to demonstrate that the concept of electrochemically induced selfassembly of TA-Fe(III) can be generalized to other polyphenols (Figure S-9 in SI).

\section{Conclusion}


In summary, a new electrotriggered self-assembly of MPN nanocoatings was developed using a morphogenic approach. TA-Fe(III) nanofilms were self-assembled using a mixture of $\mathrm{Fe}(\mathrm{II})$ and TA on which an anodic current was applied leading to the oxidation of $\mathrm{Fe}(\mathrm{II})$ into $\mathrm{Fe}(\mathrm{III})$ at the surface of the electrode. The confined electro-generated gradient of Fe(III) allowed controlling the buildup of TA-Fe(III) film, based on di- and tri-coordinated complexes, depending on the current density, the buildup $\mathrm{pH}$ and $\mathrm{Fe}(\mathrm{II}) / \mathrm{TA}$ molar ratio of the building solution. The film thickness and the self-assembly kinetic could be tuned by the application time and the value of the current density and $\mathrm{Fe}(\mathrm{II}) / \mathrm{TA}$ molar ratio of the building solution. We showed that this strategy should be applicable to other polyphenols. This new electrotriggered confined selfassembly of metal - polyphenol gives new perspectives for the development anti-oxidant coatings or as functionalizable platform. ${ }^{69}$

\section{ASSOCIATED CONTENT}

Supporting Information. Complementary characterization of TA-Fe(III) self-assembled films obtained by QCM, XPS and AFM, stability of TA-Fe(III) self-assembled film towards reductive potentials and generalization to two other polyphenols. This material is available free of charge via the Internet at http://pubs.acs.org.

\section{AUTHOR INFORMATION}

\section{Corresponding Author}

*Fouzia Boulmedais E-mail: fouzia.boulmedais@ics-cnrs.unistra.fr; phone: +33-3-88-41-41-60.

\section{Author Contributions}


The manuscript was written through contributions of all authors. All authors have given approval to the final version of the manuscript.

\section{ACKNOWLEDGMENT}

C.M. and L. L. were supported by a fellowship from the "Ministère de la Recherche et de la

Technologie". P. L. was supported by a post-doctoral fellowship from University of Strasbourg Institute for Advanced Study (USIAS). The authors gratefully acknowledge financial support from Agence Nationale de la Recherche (ANR JCJC Morphobuildup: ANR-13-JS08-0003-01), USIAS and Labex CSC.

\section{References}

(1) Webber, M. J.; Appel, E. A.; Meijer, E. W.; Langer, R. Supramolecular Biomaterials. Nat Mater 2016, 15, 13-26.

(2) Whitesides, G. M.; Boncheva, M. Beyond Molecules: Self-Assembly of Mesoscopic and Macroscopic Components. Proc. Natl. Acad. Sci. U. S. A. 2002, 99, 4769-4774.

(3) Vigier-Carriere, C.; Garnier, T.; Wagner, D.; Lavalle, P.; Rabineau, M.; Hemmerle, J.;

Senger, B.; Schaaf, P.; Boulmedais, F.; Jierry, L. Bioactive Seed Layer for Surface-Confined Self-Assembly of Peptides. Angew. Chem., Int. Ed. Engl. 2015, 54, 10198-10201.

(4) Decher, G. Fuzzy Nanoassemblies: Toward Layered Polymeric Multicomposites. Science 1997, 277, 1232-1237.

(5) Ejima, H.; Richardson, J. J.; Liang, K.; Best, J. P.; van Koeverden, M. P.; Such, G. K.; Cui, J.; Caruso, F. One-Step Assembly of Coordination Complexes for Versatile Film and Particle Engineering. Science 2013, 341, 154-157.

(6) Friese, V. A.; Kurth, D. G. From Coordination Complexes to Coordination Polymers through Self-Assembly. Curr Opin Colloid In 2009, 14, 81-93.

(7) Hunter, G. K.; Goldberg, H. A. Nucleation of Hydroxyapatite by Bone Sialoprotein. Proc. Natl. Acad. Sci. U. S. A. 1993, 90, 8562-8565.

(8) Potter, J. D. Morphogens, Morphostats, Microarchitecture and Malignancy. Nat. Rev. Cancer 2007, 7, 464-474.

(9) Maerten, C.; Jierry, L.; Schaaf, P.; Boulmedais, F. Review of Electrochemically Triggered Macromolecular Film Buildup Processes and Their Biomedical Applications. ACS Appl. Mater. Interfaces 2017, 9, 28117-28138.

(10) Krylova, I. Painting by Electrodeposition on the Eve of the 21st Century. Prog. Org. Coat. 2001, 42, 119-131. 
(11) Wu, L. Q.; Gadre, A. P.; Yi, H. M.; Kastantin, M. J.; Rubloff, G. W.; Bentley, W. E.; Payne, G. F.; Ghodssi, R. Voltage-Dependent Assembly of the Polysaccharide Chitosan onto an Electrode Surface. Langmuir 2002, 18, 8620-8625.

(12) Boccaccini, A. R.; Keim, S.; Ma, R.; Li, Y.; Zhitomirsky, I. Electrophoretic Deposition of Biomaterials. J. R. Soc. Interface 2010, 7, S581-S613.

(13) Ngankam, A. P.; Van Tassel, P. R. Continuous Polyelectrolyte Adsorption under an Applied Electric Potential. Proc. Natl. Acad. Sci. U. S. A. 2007, 104, 1140-1145.

(14) Olsen, C.; Van Tassel, P. R. Polyelectrolyte Adsorption Kinetics under an Applied Electric Potential: Strongly Versus Weakly Charged Polymers. J. Colloid Interface Sci. 2009, 329, 222227.

(15) Shi, X. W.; Tsao, C. Y.; Yang, X. H.; Liu, Y.; Dykstra, P.; Rubloff, G. W.; Ghodssi, R.; Bentley, W. E.; Payne, G. F. Electroaddressing of Cell Populations by Co-Deposition with Calcium Alginate Hydrogels. Adv. Funct. Mater. 2009, 19, 2074-2080.

(16) Cheng, Y.; Tsao, C. Y.; Wu, H. C.; Luo, X. L.; Terrell, J. L.; Betz, J.; Payne, G. F.; Bentley, W. E.; Rubloff, G. W. Electroaddressing Functionalized Polysaccharides as Model Biofilms for Interrogating Cell Signaling. Adv. Funct. Mater. 2012, 22, 519-528.

(17) Johnson, E. K.; Adams, D. J.; Cameron, P. J. Directed Self-Assembly of Dipeptides to Form Ultrathin Hydrogel Membranes. J. Am. Chem. Soc. 2010, 132, 5130-5136.

(18) Liu, Y.; Cheng, Y.; Wu, H. C.; Kim, E.; Ulijn, R. V.; Rubloff, G. W.; Bentley, W. E.; Payne, G. F. Electroaddressing Agarose Using Fmoc-Phenylalanine as a Temporary Scaffold. Langmuir 2011, 27, 7380-7384.

(19) Leisk, G. G.; Lo, T. J.; Yucel, T.; Lu, Q.; Kaplan, D. L. Electrogelation for Protein Adhesives. Adv. Mater. 2010, 22, 711-715.

(20) Wong, I. Y.; Footer, M. J.; Melosh, N. A. Electronically Activated Actin Protein Polymerization and Alignment. J. Am. Chem. Soc. 2008, 130, 7908-7915.

(21) Waltman, R. J.; Bargon, J. Electrically Conducting Polymers - a Review of the Electropolymerization Reaction, of the Effects of Chemical-Structure on Polymer Film Properties, and of Applications Towards Technology. Can. J. Chem. 1986, 64, 76-95. (22) Rydzek, G.; Ji, Q. M.; Li, M.; Schaaf, P.; Hill, J. P.; Boulmedais, F.; Ariga, K. Electrochemical Nanoarchitectonics and Layer-by-Layer Assembly: From Basics to Future. Nano Today 2015, 10, 138-167.

(23) Rydzek, G.; Jierry, L.; Parat, A.; Thomann, J. S.; Voegel, J. C.; Senger, B.; Hemmerle, J.; Ponche, A.; Frisch, B.; Schaaf, P.; Boulmedais, F. Electrochemically Triggered Assembly of Films: A One-Pot Morphogen-Driven Buildup. Angew. Chem., Int. Ed. Engl. 2011, 50, 43744377.

(24) Kolb, H. C.; Finn, M. G.; Sharpless, K. B. Click Chemistry: Diverse Chemical Function from a Few Good Reactions. Angew. Chem., Int. Ed. Engl. 2001, 40, 2004-2021.

(25) Dochter, A.; Garnier, T.; Pardieu, E.; Chau, N. T. T.; Maerten, C.; Senger, B.; Schaaf, P.; Jierry, L.; Boulmedais, F. Film Self-Assembly of Oppositely Charged Macromolecules Triggered by Electrochemistry through a Morphogenic Approach. Langmuir 2015, 31, 1020810214.

(26) Faure, E.; Falentin-Daudre, C.; Jerome, C.; Lyskawa, J.; Fournier, D.; Woisel, P.; Detrembleur, C. Catechols as Versatile Platforms in Polymer Chemistry. Prog. Polym. Sci. 2013, $38,236-270$.

(27) Sedo, J.; Saiz-Poseu, J.; Busque, F.; Ruiz-Molina, D. Catechol-Based Biomimetic Functional Materials. Adv. Mater. 2013, 25, 653-701. 
(28) Deming, T. J. Mussel Byssus and Biomolecular Materials. Curr. Opin. Chem. Biol. 1999, 3, 100-105.

(29) Maerten, C.; Garnier, T.; Lupattelli, P.; Chau, N. T. T.; Schaaf, P.; Jierry, L.; Boulmedais, F. Morphogen Electrochemically Triggered Self-Construction of Polymeric Films Based on Mussel-Inspired Chemistry. Langmuir 2015, 31, 13385-13393.

(30) Erel-Unal, I.; Sukhishvili, S. A. Hydrogen-Bonded Multilayers of a Neutral Polymer and a Polyphenol. Macromolecules 2008, 41, 3962-3970.

(31) Ball, V. Permeabilty of Silver Cations through (Pah-Pss)(M) Polyelectrolyte Multilayer Films to Deposit Silver in Underlying (Pah-Tannic Acid)(N) Film without External Reducing Agent at Ph 5.0. Colloids Surf., A 2015, 484, 70-74.

(32) Lomova, M. V.; Brichkina, A. I.; Kiryukhin, M. V.; Vasina, E. N.; Pavlov, A. M.; Gorin, D. A.; Sukhorukov, G. B.; Antipina, M. N. Multilayer Capsules of Bovine Serum Albumin and Tannic Acid for Controlled Release by Enzymatic Degradation. ACS Appl. Mater. Interfaces 2015, 7, 11732-11740.

(33) Ringwald, C.; Ball, V. Step-by-Step Deposition of Type B Gelatin and Tannic Acid Displays a Peculiar Ionic Strength Dependence at Ph 5. RSC Adv. 2016, 6, 4730-4738.

(34) Xu, G.; Pranantyo, D.; Zhang, B.; Xu, L. Q.; Neoh, K. G.; Kang, E. T. Tannic Acid Anchored Layer-by-Layer Covalent Deposition of Parasin I Peptide for Antifouling and Antimicrobial Coatings. RSC Adv. 2016, 6, 14809-14818.

(35) Hizal, F.; Zhuk, I.; Sukhishvili, S.; Busscher, H. J.; van der Mei, H. C.; Choi, C. H. Impact of $3 \mathrm{~d}$ Hierarchical Nanostructures on the Antibacterial Efficacy of a Bacteria-Triggered SelfDefensive Antibiotic Coating. ACS Appl. Mater. Interfaces 2015, 7, 20304-20313.

(36) Rahim, M. A.; Ejima, H.; Cho, K. L.; Kempe, K.; Mullner, M.; Best, J. P.; Caruso, F. Coordination-Driven Multistep Assembly of Metal-Polyphenol Films and Capsules. Chem. Mater. 2014, 26, 1645-1653.

(37) Ringwald, C.; Ball, V. Layer-by-Layer Deposition of Tannic Acid and Fe3+ Cations Is of Electrostatic Nature but Almost Ionic Strength Independent at Ph 5. J. Colloid Interface Sci. 2015, 450, 119-126.

(38) Yang, L. W.; Han, L. L.; Ren, J.; Wei, H. L.; Jia, L. Y. Coating Process and Stability of Metal-Polyphenol Film. Colloids Surf., A 2015, 484, 197-205.

(39) Guo, J.; Ping, Y.; Ejima, H.; Alt, K.; Meissner, M.; Richardson, J. J.; Yan, Y.; Peter, K.; von Elverfeldt, D.; Hagemeyer, C. E.; Caruso, F. Engineering Multifunctional Capsules through the Assembly of Metal-Phenolic Networks. Angew. Chem., Int. Ed. Engl. 2014, 53, 5546-5551. (40) Rahim, M. A.; Kempe, K.; Mullner, M.; Ejima, H.; Ju, Y.; van Koeverden, M. P.; Suma, T.; Braunger, J. A.; Leeming, M. G.; Abrahams, B. F.; Caruso, F. Surface-Confined Amorphous Films from Metal-Coordinated Simple Phenolic Ligands. Chem. Mater. 2015, 27, 5825-5832. (41) Ejima, H.; Richardson, J. J.; Caruso, F. Metal-Phenolic Networks as a Versatile Platform to Engineer Nanomaterials and Biointerfaces. Nano Today 2017, 12, 136-148.

(42) You, F.; Xu, Y.; Yang, X.; Zhang, Y.; Shao, L. Bio-Inspired Ni2+-Polyphenol Hydrophilic Network to Achieve Unconventional High-Flux Nanofiltration Membranes for Environmental Remediation. Chem. Commun. 2017, 53, 6128-6131.

(43) Ping, Y.; Guo, J.; Ejima, H.; Chen, X.; Richardson, J. J.; Sun, H.; Caruso, F. Ph-Responsive Capsules Engineered from Metal-Phenolic Networks for Anticancer Drug Delivery. Small 2015, 11, 2032-2036. 
(44) Park, J. H.; Kim, K.; Lee, J.; Choi, J. Y.; Hong, D.; Yang, S. H.; Caruso, F.; Lee, Y.; Choi, I. S. A Cytoprotective and Degradable Metal-Polyphenol Nanoshell for Single-Cell Encapsulation. Angewandte Chemie-International Edition 2014, 53, 12420-+.

(45) Krogsgaard, M.; Nue, V.; Birkedal, H. Mussel-Inspired Materials: Self-Healing through Coordination Chemistry. Chem-Eur J 2016, 22, 844-857.

(46) Rahim, M. A.; Bjornmalm, M.; Suma, T.; Faria, M.; Ju, Y.; Kempe, K.; Mullner, M.; Ejima, H.; Stickland, A. D.; Caruso, F. Metal-Phenolic Supramolecular Gelation. Angew. Chem., Int. Ed. Engl. 2016, 55, 13803-13807.

(47) Rahim, M. A.; Bjornmalm, M.; Bertleff-Zieschang, N.; Besford, Q.; Mettu, S.; Suma, T.; Faria, M.; Caruso, F. Rust-Mediated Continuous Assembly of Metal-Phenolic Networks. Adv. Mater. 2017, 29, 1606717.

(48) Rahim, M. A.; Björnmalm, M.; Bertleff-Zieschang, N.; Ju, Y.; Mettu, S.; Leeming, M. G.; Caruso, F. Multiligand Metal-Phenolic Assembly from Green Tea Infusions. ACS Appl. Mater. Interfaces, DOI: 10.1021/acsami.7b09237.

(49) Hingston, F. J. Activity of Polyphenolic Constituents of Leaves of Eucalyptus and Other Species in Complexing and Dissolving Iron Oxide. Aust. J. Soil Res 1963, 1, 63-73.

(50) Ameloot, R.; Stappers, L.; Fransaer, J.; Alaerts, L.; Sels, B. F.; De Vos, D. E. Patterned Growth of Metal-Organic Framework Coatings by Electrochemical Synthesis. Chem. Mater. 2009, 21, 2580-2582.

(51) Li, W. J.; Lu, J.; Gao, S. Y.; Li, Q. H.; Cao, R. Electrochemical Preparation of MetalOrganic Framework Films for Fast Detection of Nitro Explosives. J Mater Chem A 2014, 2, 19473-19478.

(52) Singh, K.; McArdle, T.; Sullivan, P. R.; Blanford, C. F. Sources of Activity Loss in the Fuel Cell Enzyme Bilirubin Oxidase. Energ Environ Sci 2013, 6, 2460-2464.

(53) Nagasaka, M.; Yuzawa, H.; Horigome, T.; Hitchcock, A. P.; Kosugi, N. Electrochemical Reaction of Aqueous Iron Sulfate Solutions Studied by Fe L-Edge Soft X-Ray Absorption Spectroscopy. J. Phys. Chem. C 2013, 117, 16343-16348.

(54) Kisler, K.; Kim, B. N.; Liu, X.; Berberian, K.; Fang, Q.; Mathai, C. J.; Gangopadhyay, S.; Gillis, K. D.; Lindau, M. Transparent Electrode Materials for Simultaneous Amperometric Detection of Exocytosis and Fluorescence Microscopy. J Biomater Nanobiotechnol 2012, 3, 243 253.

(55) Wan, H. J.; Zou, Q. L.; Yan, R.; Zhao, F. Q.; Zeng, B. Z. Electrochemistry and Voltammetric Determination of Tannic Acid on a Single-Wall Carbon Nanotube-Coated Glassy Carbon Electrode. Microchimica Acta 2007, 159, 109-115.

(56) Lee, H.; Dellatore, S. M.; Miller, W. M.; Messersmith, P. B. Mussel-Inspired Surface Chemistry for Multifunctional Coatings. Science 2007, 318, 426-430.

(57) Ye, Q.; Zhou, F.; W., L. Bioinspired Catecholic Chemistry for Surface Modification Chem. Soc. Rev. 2011, 40, 4244-4258.

(58) Burzio, L. A.; Waite, J. H. Cross-Linking in Adhesive Quinoproteins: Studies with Model Decapeptides. Biochemistry 2000, 39, 11147-11153.

(59) Yang, L.; Han, L.; Ren, J.; Wei, H.; Jia, L. Coating Process and Stability of MetalPolyphenol Film. Colloids and Surfaces A: Physicochem. Eng. Aspects 2015, 484, 197-205. (60) Moulder, J. F.; Stickle, W. F.; Sobol, P. E.; Bomben, K. D. Handbook of X-Ray Photoelectron Spectroscopy; Physical Electronics: Chanhassen, MN, 1995.

(61) Huang, X.; Liao, X.; Shi, B. Hg(Ii) Removal from Aqueous Solution by Bayberry TanninImmobilized Collagen Fiber. J. Hazard. Mater. 2009, 170, 1141-1148. 
(62) Gust, J.; Suwalski, J. Use of Mossbauer-Spectroscopy to Study Reaction-Products of Polyphenols and Iron Compounds. Corrosion 1994, 50, 355-365.

(63) Mander, L.; Liu, H. W. Comprehensive Natural Products Ii: Chemistry and Biology; Elsevier: Kildington, U. K., 2010; Vol. 1.

(64) d'Ischia, M.; Napolitano, A.; Ball, V.; Chen, C. T.; Buehler, M. J. Polydopamine and Eumelanin: From Structure-Property Relationships to a Unified Tailoring Strategy. Acc. Chem. Res. 2014, 47, 3541-3550.

(65) Mu, S. L.; Chen, C. Electrochemical Oxidation of Pyrogallol: Formation and Characterization of Long-Lived Oxygen Radicals and Application to Assess the Radical Scavenging Abilities of Antioxidants. J. Phys. Chem. B 2012, 116, 12567-12573. (66) Mochizuki, M.; Yamazaki, S.; Kano, K.; Ikeda, T. Kinetic Analysis and Mechanistic Aspects of Autoxidation of Catechins. Biochim. Biophys. Acta, Gen. Subj. 2002, 1569, 35-44. (67) Ross, T. K.; Francis, R. A. The Treatment of Rusted Steel with Mimosa Tannin. Corros. Sci. 1978, 18, 351-361.

(68) Avdeef, A.; Sofen, S. R.; Bregante, T. L.; Raymond, K. N. Coordination Chemistry of Microbial Iron Transport Compounds .9. Stability-Constants for Catechol Models of Enterobactin. J. Am. Chem. Soc. 1978, 100, 5362-5370.

(69) Sileika, T. S.; Barrett, D. G.; Zhang, R.; Lau, K. H. A.; Messersmith, P. B. Colorless Multifunctional Coatings Inspired by Polyphenols Found in Tea, Chocolate, and Wine. Angew. Chem., Int. Ed. Engl. 2013, 52, 10766-10770. 
TOC:

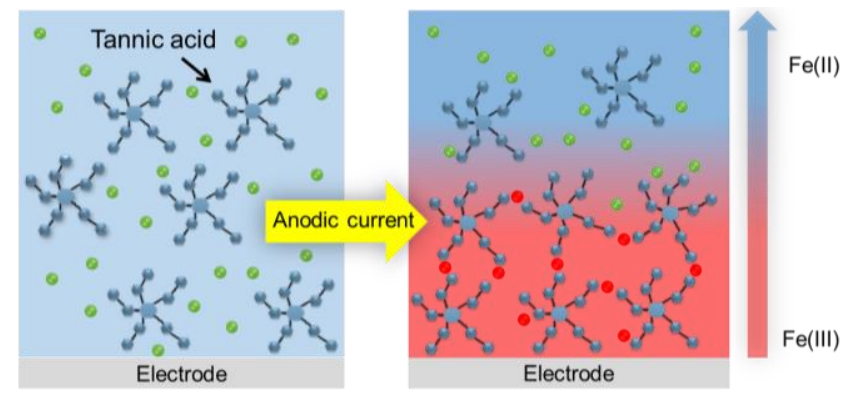

